Historic, Archive Document

Do not assume content reflects current scientific knowledge, policies, or practices. 



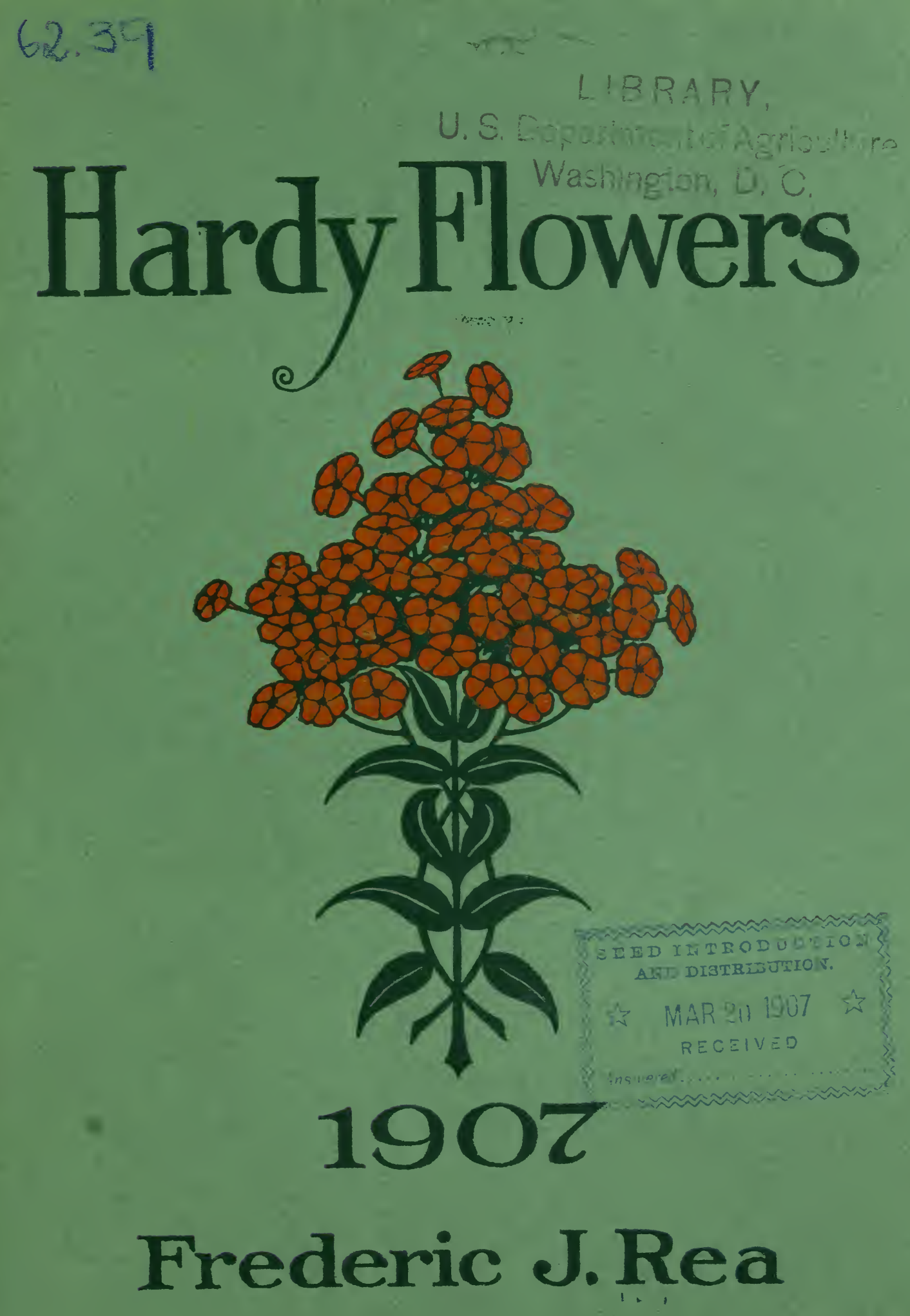





\section{Catalogue of Popular Hardy}

\section{Herbaceous Perennials}

Roses, Shrubs, Vines, Etc.

Norwood Nurseries

FREDERIC J. REA,

NORWOOD, MASS. 


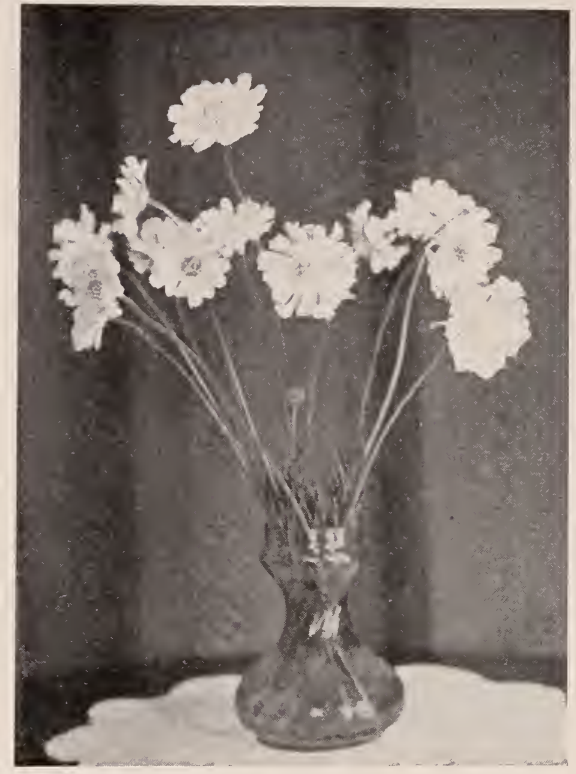

SCABIOSA CAUCASICA. SEE PAGE 30.

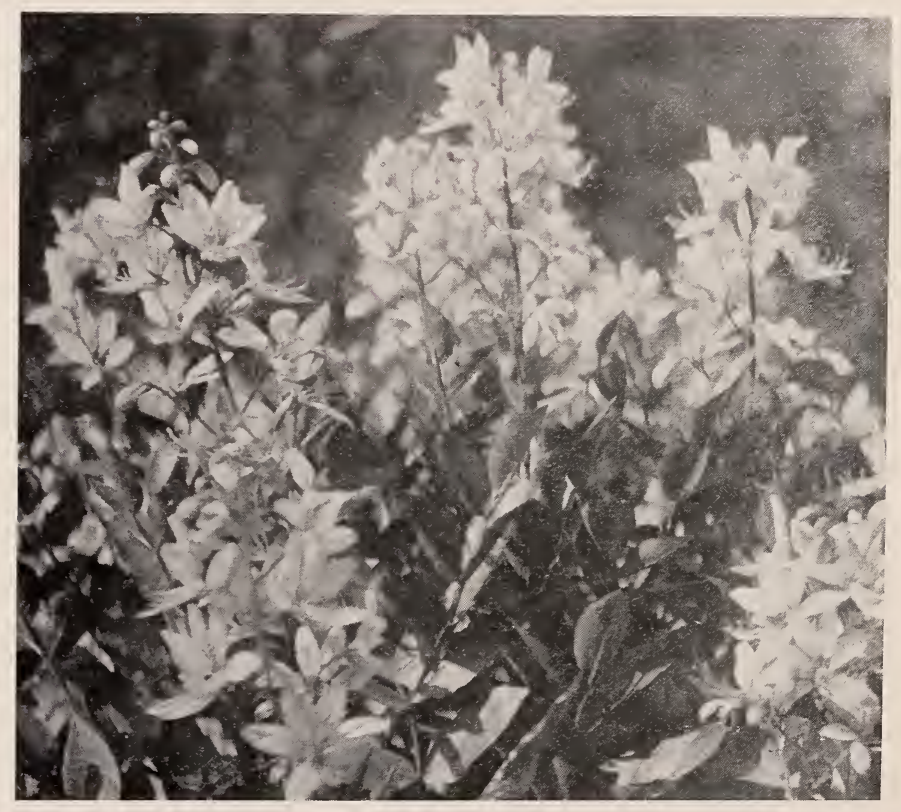

DICTAMNUS FRAXINELLA. SEE PAGE $23 \cdot$ 


\section{Notice to Customers.}

I shall be pleased to see visitors at the Nurseries, and shall arrange to be there on Monday of each week, or if preferred, appointments may be made by letter or telephone.

The nearest railroad station is Norwood Central (about fifteen minutes' walk) on the Midland Division of the N. Y., N. H. \& H. R. R. Electric cars can be taken from Forest Hills to Dean St., Norwood-one hour's ride.

Customers are requested to state whether they wish their plants sent by mail, express or freight.

To avoid mistakes or delays, please see that name and full address are plainly given.

EVERY CARE is taken in packing so as to ensure the arrival of plants in good condition, but I cannot be held responsible for any loss or damage through delay, or any other cause during transit.

If plants are not satisfactory, or there are any mistakes, please notify me immediately.

COMPLAINTS cannot be entertained unless made within ten days after receipt of plants.

My stock is free from all diseases, and has been officially inspected.

Certificate of inspection accompanies each shipment. 


\section{A Few Remarks Concerning Old Fashioned Plants.}

The popularity of these Old Fashioned Garden Plants is becoming more marked every year, and deservedly so.

There is not an ornamental plant grown that can compare with these in attractiveness, beauty and usefulness, and there seems to be always something new and different every day to admire in a garden of these plants.

Among the most popular and well known varieties are Coreopsis, Larkspurs, Bell-Flowers, Poppies, Peonies, Iris, Hollyhocks, Phloxes, etc.

These plants require comparatively little care when once they are planted, as they come up and flower successively year after year.

In planting an Herbaceous Perennial Garden it is always advisable to make a rough plan so that you can tell the best place to plant everything you wish to put in, and what is of very great importance, it will help to keep the colors properly blended, and also help to arrange them with better effect regarding their flowering season.

This time of flowering must not be lost sight of if you wish to avoid clashing of colors, and in this catalogue you will find the month of flowering given, as well as the color.

If a little thought is given in choosing varieties a continuous display may be had from April till October.

Always plant, as far as it is possible, in masses, as this is the most natural way and also the most effective.

Nearly all species that are found wild are in masses. It is more satisfactory in most instances to plant a limited number of varieties in masses than to fill up your space with single plants in more variety.

Always cut off the flower stems as soon as flowers have gone by, as the garden will look better and the individual plants be greatly benefited, and in some cases a second period of bloom will result. 


\section{Novelties and Other Especially Desirable Plants.}

\section{ALYSSUM SAXATILE PLENUM.}

A distinct new form of the Gold-Tuft, with quantities of

Each. Dozen.

double golden yellow flowers in early spring. Height

6 inches. From $2 \frac{1}{2}$ inch pots.

\section{ANCHUSA ITALICA-DROPMORE VAR.}

A very great improvement in the borage family, having much larger flowers, color of an exquisite deep blue on spikes, 2 $1 / 2-3$ feet high and a 2-3 foot spread. A beautiful plant. 4 inch pots.

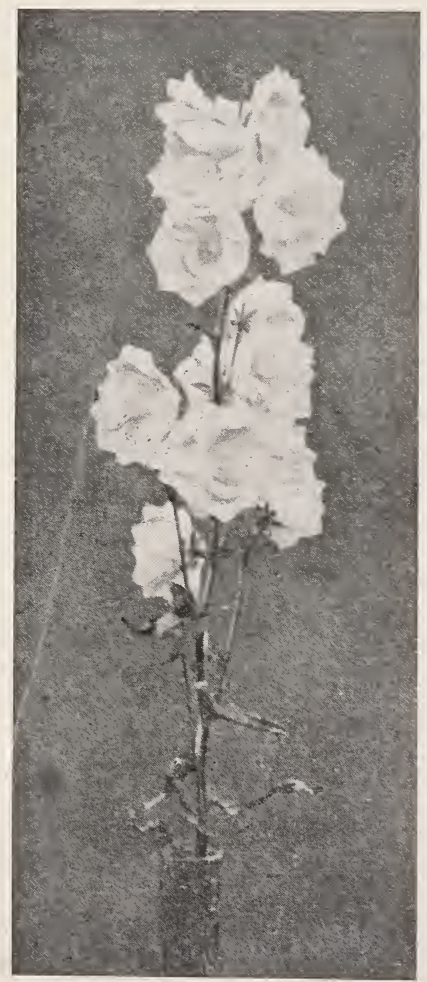

CAMPANULA PERSICIFOLIA MOERHEIMII,

\section{ASTILBE DAVIDII.}

A new introduction from China with handsome tufted foliage and graceful, compound flower spikes, attaining an height of from 4-6 feet, color of a distinct reddish purple, coming into bloom in July.

CAMPANULA PERSICIFOLIA GRANDIFLORA-REA'S VARIETY.

Awarded a First-class Certificate of Merit by the Massachusetts Horticultural Society, rgoo. A very handsome variety with tall spikes of large clear purple blue flowers. Superior in every way to forms usually sent under this name. Height, 2-3 feet. June. 
CAMPANULA PERSICIFOLIA ALBA GRANDIFLORA GIGANTEA FL. PL. ( MOERHEIMII) -New.

The most beautiful of all the peach-leaved Campanulas, Each. Dozen. for which I was awarded a Silver Medal by the Massachusetts Horticultural Society. It is very strong growing and has extra large flowers, borne on erect, sturdy stems, in close spikes. The flowers are pure white, three inches across, well open. The several rows of petals are arranged alternate$1 y$, giving a flower that, although large and double, is yet light and dainty. See cut. Height, 2-3 feet. June.

\section{HARDY CHRYSANTHEMUMS.}

These, within the last few years, have become very popular, as they come into bloom about the last of September, and continue in beauty throughout October. They are very showy and useful for cutting purposes. The following are among the most distinct varieties. When planted in May or June they make a fine showing the following fall. From $21 / 2$ inch pots.

Blushing Beauty-White, edged pink, pompon.

Blushing Bride-Clear pink, pompon.

Boston-Dark bronze red.

Canovia-Orange yellow.

Constance-Shell pink, semi-double.

Eagle D'or-Large yellow.

Fred Peel-Light lilac, pompon.

Gloire de France-White, shaded pink, pompon.

Golden Fleece-Deep golden yellow.

Ivanhoe-Dark pink.

James Boone-Creamy white, pompon.

Jeannette-Yellow, tipped bronze, pompon.

Mrs. Porter-Bronze.

Northumberland-Bright red.

Sadie-Bright yellow.

Santiago-Bronze, tipped yellow, pompon.

St. Crousse-Deep brick red, pompon.

Sunset-Scarlet bronze, golden yellow.

Thalia-Small pure white. 
CHRYSANTHEMUM MAXIMUM-“KING EDWARD."

This is pronounced the largest and finest C. maximum ever Each. Dozen. seen. It is a free bloomer, grows $2-2 \frac{1}{2}$ feet high, with composite flowers of purest white. fully 4-5 inches in diameter, in bloom from July till frost. 4 inch pots. See cut.

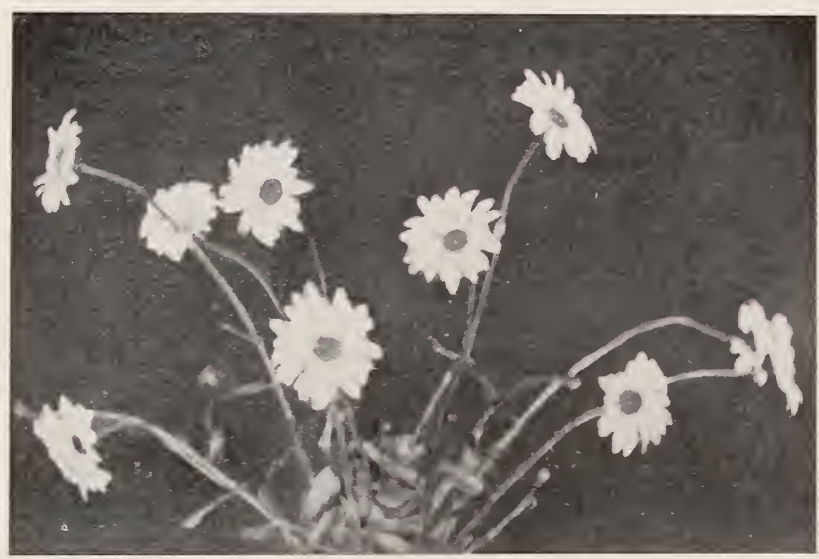

CHRYSANTHEMUM MANMLM-"KING EDWARD."

\section{CLEMATIS MONGOLICA.}

A new introduction from China in habit resembling Clematis recta. It attains a height of from 5-6 feet when thoroughly established, has good foliage, and produces in June and July an abundance of pure white flowers similar to the well-known Clematis paniculata. The seed heads are also very attractive through September. A very desirable novelty. Strong flowering plants.

\section{DIANTHUS PLUMARIUS NANUS FL. PL.}

A new strain of the Garden Pink, of recent introduction, ranging in color from pure white to deep red, with intermediate shades and variations. The flowers are mostly double, sweet-scented, and excellent for cutting purposes. A fine plant for edging. Height, 6 inches. Flowers in great profusion in June. 


\section{GEUM HELDREICHI SPLENDENS.}

Very large orange colored flowers of great beauty. The flowers are similar to a Potentilla. Divided dark green foliage. 2 feet. July.

Each. Dozen.

\section{GYPSOPHILA PANICULATA PLENA.}

Those who are familiar with the single form of this, will appreciate a double form as a great improvement in its lasting qualities and whiter effect. Fine for cutting. See cut. 2-3 feet. July. Strong plants from 4 inch pots.

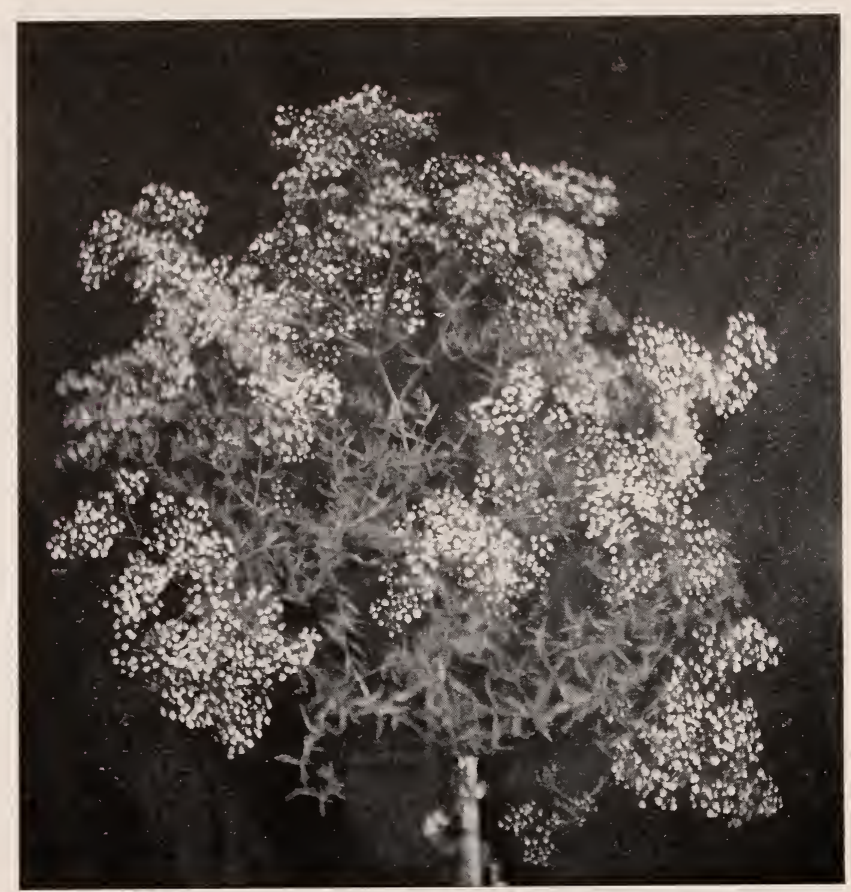

GYPSOPHILA PANICULATA PLENA.

\section{GYNERIUM ARGENTEUM-(PAMPAS GRASS.)}

An old favorite. Immense plumes attaining an height of from 6-8 feet, graceful foliage. Not hardy in New England, should be lifted and stored every fall. 


\section{HELENIUM AUTUMNALE SUPERBUM RUBRUM.}

A splendid acquisition. Everybody will appreciate at Each. once the value of a tall fall blooming red flowered perennial. The deep ox-blood red flowers are borne on tall branching spikes. There are one or two other red Heleniums, but those that have seen this one, claim its superiority. Height $5^{-6}$ feet. September. Stock limited. Single crowns. $\quad \begin{array}{lll}\$ .25 & \$ 2.50\end{array}$

\section{HELENIUM PUMILUM MAGNIFICUM.}

A handsome new variety, being a cross between $H$. pumilum and $H$. autumnale superbum. It grows $2 \frac{1}{2}$ feet high, having an abundance of large yellow flowers, and blooming nearly all through the summer.

\section{HEMEROCALLIS FLAMID.}

This is a new variety of the Day Lily, with clear orange yellow flowers, sweet-scented, and growing about $2 \mathrm{I} / 2$ feet high. June.

\section{INCARVILLEA DELAVAYI.}

One of the handsomest perennials of recent introduction. Flowers are large, tubular, similar to the trumpet vine (belonging to the same order). 2-3 inches long and as much wide, color rosy-purple. I-2 feet. Summer.

\section{IRIS GERMANICA.}

It is hardly necessary to describe this well-known family of Fleurde-lis. On account of the richness and beauty of the flowers they are sometimes called Hardy Orchids. In height they vary from 2 to 3 feet, blooming in June. The list here given comprises the best varieties to be had. In the descriptions S.- -standards, or three upright petals, and F.falls, or three drooping petals. See cut.

Aphylla-S. and F. white, fringed purple.

Aurea-S. and F. yellow.

$.25 \quad 2.50$

Cordelia-S. lilac; F. rich velvety purple, lilac margin.

Darius-S. bright yellow; F. purple veined and edged

Fair Maid-S. white; F. white, slightly tinged lavender. 
Flavescens-S. and F. delicate pale yellow.

Gracchus-S. light yellow; F. crimson, veined white.

Gypsy Queen -S. coppery yellow; F. rich maroon.

H. Cramer-S. and F. delicate pale lavender; F. darker.

$\begin{array}{cr}\text { Each. } & \text { Dozen. } \\ \$ .20 & \$ 2.00 \\ .25 & 2.50 \\ .35 & 3.50 \\ .20 & 2.00 \\ .35 & 3.50 \\ .15 & 1.50 \\ .25 & 2.50 \\ .35 & 3.50 \\ .15 & 1.50 \\ .25 & 2.50 \\ .20 & 2.00\end{array}$

Her Majesty-S. and F. handsome rosy purple; F. darker

Honorablis - S. golden yellow; F. yellow and bronze.

Innocenza-S. and F. large white.

Macrantha-S. deep violet; F. rich purple.

Mme. Chereau-S. and F. white, fringed with pale violet.

Mme. Paquette-S. and F. rosy lilac; F. deeper.

Maori King-S. golden yellow; F. rich brown.

Mrs. H. Darwin-S. snow white; F. white, slightly veined purple.

Queen of May-S. and F. delicate soft lilac, slightly tinted pink.

Rowlandiana-S. cream white; F. deep purple, veined white.

Victorine-S. pure white blotched purple; F. deep purple, reined white.

$\begin{array}{ll}.25 & 2.50 \\ .35 & 3.5^{\circ}\end{array}$

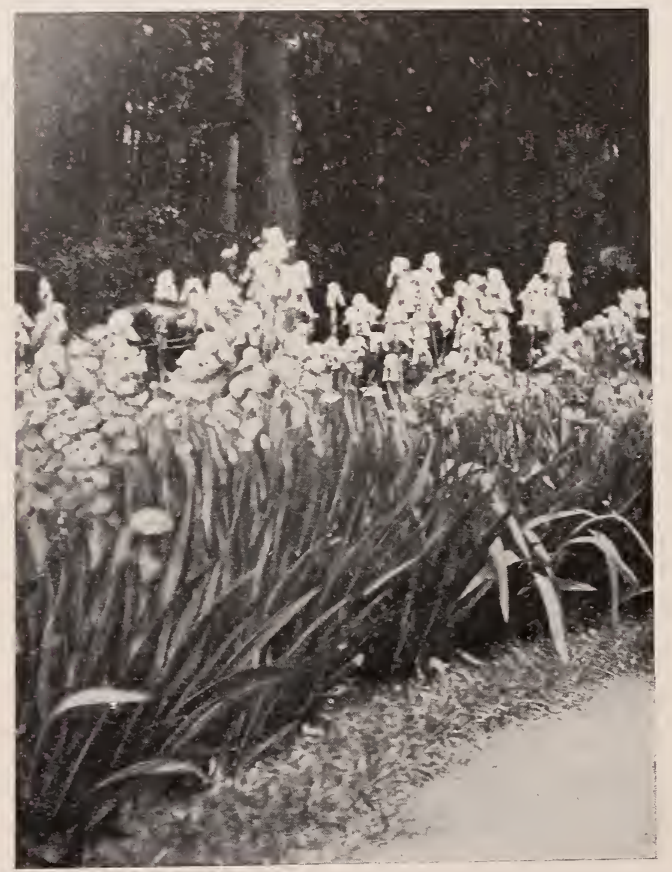

IRIS GERMIANICA. GROUP. 


\section{IRIS GERMANICA-MME. NEUBRONNER.}

$S$. and F. clear golden yellow, the finest yellow yet intro-

Each. Dozen duced.

IRIS KAEMPFERI-(JAPANESE IRIS).

With the possible exception of the German, the Japanese take the lead in Iris. The single flower is one of the largest blooms in cultivation. They range in shades of color in white, purple, blue and rosy lilac; there are no yellows or red, although a little yellow is found at the base of some of the petals. The standard or inner petals are short, giving the flowers a flat appearance. Give lots of water from middle of June till flowers are gone by. 3-4 feet. July. I 2 distinct varieties.

\section{LYCHNIS FLOS-CUCULI ALBA PLENA.}

Double White Cuckoo Flower. Tufts of light green foliage, upright branched flower stems producing numerous pure white feathery flowers from early summer to late fall. Height, I2-I 8 inches. See cut. $2 \mathrm{t} / 2$ inch pots.

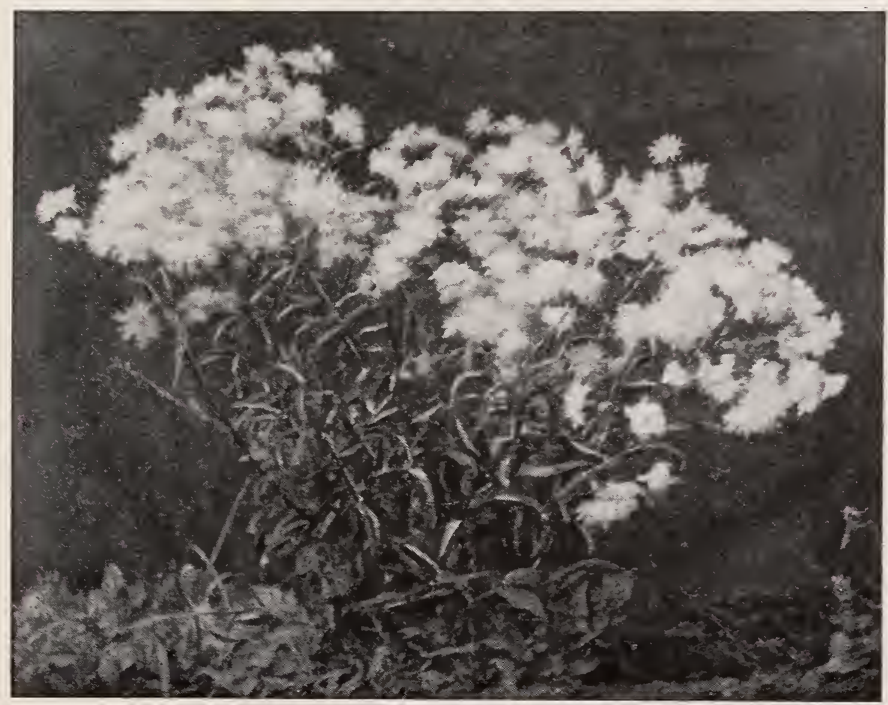




\section{CENOTHERA SPECIOSA ROSEA.}

A very rare and handsome variety of the Evening PrimEach. Dozen. rose, with large, showy, deep pink flowers. It is almost a continuous bloomer from May till September, and has rather a low, spreading habit. $21 / 2$ inch pots.

\section{ENOTHERA YOUNGII.}

Most of the evening primroses either bloom sparingly or have all the flowers at the apex of spikes; this has showy pannicles of large, bright yellow flowers from the ground up. 2 feet. June.

\section{PEONIES.}

The collection given below of this popular Queen of June is a good collection at reasonable prices. The two varieties of officinalis are a week or ten days earlier than the remainder. If my customers need a fancy collection I shall be pleased to quote prices. The varieties offered below are $.35 \mathrm{c}$ each, $\$ 3.5^{\circ}$ dozen, except as noted.

Alba plena-Pure white.

Agida-Dark red.

Beaute Francaise-Delicate rose, very full.

Candidissima-Pure white.

Chrysanthemiflora rosea-Fine rose, extra form.

Duchess d'Orleans-Very fine pink,

Edulis superba-Bright rose, extra.

Festiva maxima-Large pure white, blotched carmine. .75

General Bertrand-Rose, center white.

Hericartiana-Violet rose.

Louis Renault-Rose, late flowering.

Louis Van Houtte-Bright red.

Lutetiana-Light rose, center salmon.

Madame Breon-Flesh, changing to white.

Magnifica-White, shaded carmine, center yellowish. $\quad .5^{\circ} \quad 5.00$

Monsieur Rousselon-Rose, center white.

Officinalis rubra-Large red, early.

Officinalis alba-Large white, early.

Prolifica tricolor-White, center spotted yellow.

Pulcherrima-Soft rosy white, center salmon. 
Queen Victoria-Pure white, very free.

Each. Dozen.

Rubra triumphans-Bright crimson purple.

Rosea grandiflora-Pink, large.

\section{PHLOX SUBULATA-"VIVID."}

A very pretty variety of Moss Pink, with clear salmon pink flowers. May. Height, 4-6 inches.

\section{PHLOX DIVARICATA LAPHAMI-(WILD SWEET WILLIAM).}

A distinct variety of this well-known Phlox. The flowers are much larger and of a deeper and brighter blue. It also has a more vigorous habit. I foot. May. From $2 \frac{1}{2}$ inch pots.

\section{PRIMULA ACAULIS PLENA-(DOUBLE PRIMROSE).}

The double forms of the old English Primrose are not often seen, but they are so handsome that I offer them for sale. They should have frame culture away from the hot sun. Those offered below will not flower this year. 4-6 inches high. May. From $2 \mathrm{~T} / 2$ inch pots.

Alba plena-Double white. .20

Lilacina plena-Double lilac.

Sulphurea plena-Double yellow.

Pompadour-Double red.

\section{RANUNCULUS ACONITIFOLIUS PLENA-(FAIR MAIDS OF FRANCE).}

Spreading compound spikes of medium size, double white flowers, fine for cutting. June. $I \frac{I}{2-2}$ feet.

\section{ROMNEYA COULTERI.}

California Tree Poppy. A very rare and choice perennial, but as it is not quite hardy in the New England climate, should be lifted in the fall and treated like the soft-wooded Hydrangeas. It has a spreading, shrub-like habit, glaucous foliage, and large white flowers with prominent yellow stamens. Summer. Height, 4-5 feet. From $2 \frac{1}{2}$ inch pots. 


\section{SEDUM SPECTABILE ATROPURPUREUM.}

Very dark purple flower heads. This is a variety of the Each. Dozen. Showy Stonecrop, but much deeper in color. It has large glaucous foliage and attains the height of about 2 feet. September.

\section{TROLLIUS ASIATICUS FL. CROCEO-(GLOBE FLOWER).}

This is rather a scarce variety of the globe flower. The flowers are of a dark orange color. May. 2 feet.

\section{TROLLIUS CAUCASICUS-(FIRE GLOBE).}

Enormous flowers, and considered the finest dark orange colored trollius grown. May. 2 feet. Stock limited.

\section{VERONICA GENTIANOIDES VARIEGATA.}

A very pretty low growing plant, broad dark green oval leaves, margined broadly with white. Fine for borders or rockery. $2 \frac{1}{2}$ inch pots.

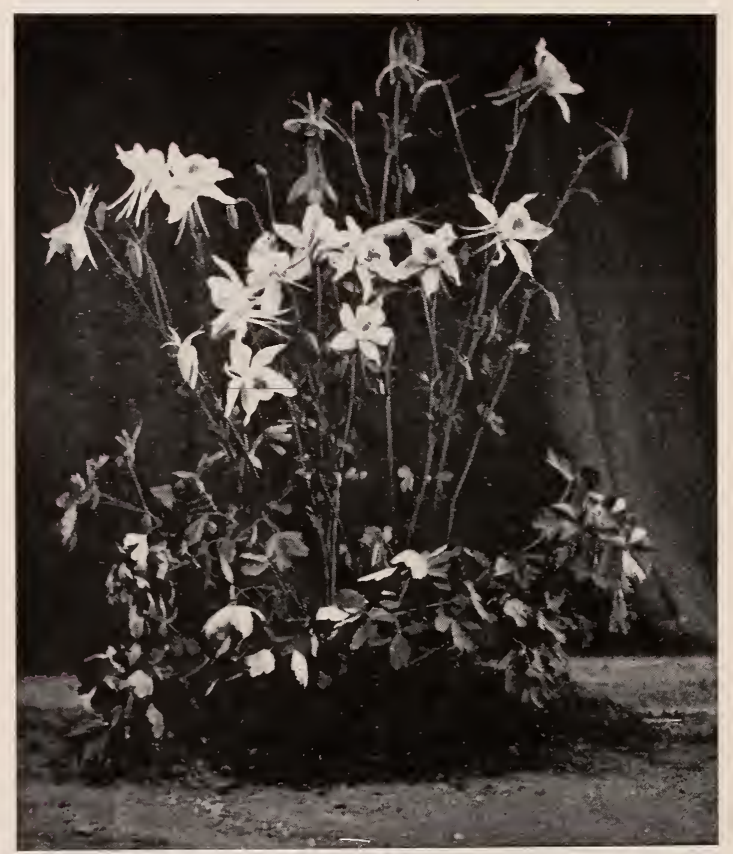

ACQUilegi.A CERULEA HYBRIDA. SEE PAGE 20. 


\section{Phlox Decussata.}

\section{HARDY PERENNIAL PHLOX.}

Phloxes are old-fashioned favorites which are becoming more popular every year. As they are one of the few flowers that bloom during the hottest part of the summer and continue in bloom through the fall, it can truly be said that no garden is complete without them.

Great improvements have been made in this flower during the last few years. The size of flower and spike is much larger, and the colors now range in nearly all shades except yellow.

The collection here offered contains the best and choicest varieties to be had.

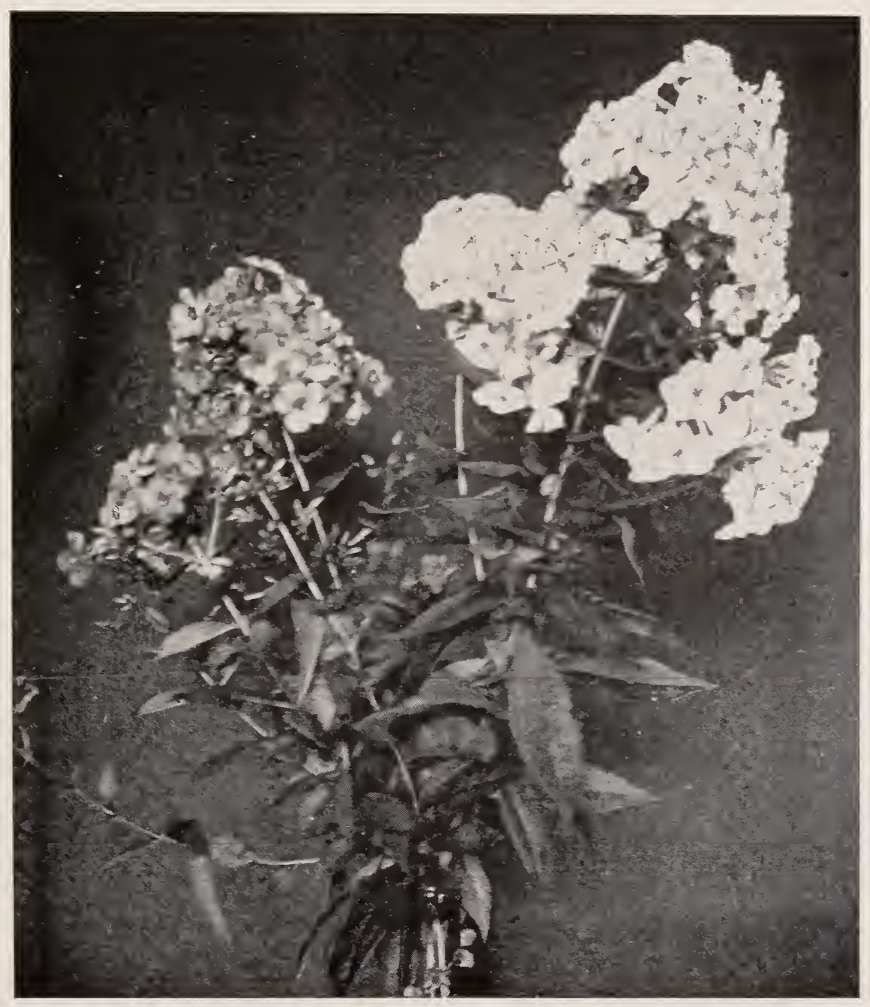




\section{TALL. 2 I-2 to 3 FEET.}

Although some of the descriptions are similar, there is a distinction which is very difficult to describe.

The best and most distinct varieties are marked thus*:

Alhambra-Light magenta, large white centre.

*Amphitryon-Lilac suffused with white, large flower.

Astier-Rehu-Bright, deep purple, half of each petal lighter shade.

*Chas. Darwin-Bright salmon pink, crimson centre, very large pyramidal spike.

*Coquelicot-Bright orange scarlet, dark crimson centre.

"Crepuscule-Very large flower, lilac, shaded lighter toward margin, very large crimson centre.

Etna-Bright red, tinted salmon, dark crimson centre.

Etoile-Bright magenta, shading to white centre.

*Fernand Cortez-Bright deep crimson, very dark centre,

bronzy effect.

*Fiancee-Pure white, very large.

*Flambeau-Bright salmon red.

Laniboire-Bright rose, slightly shaded scarlet, crimson centre.

*Le Cygne-Pure white, large flower, very large pyramidal spike.

*Le Mahdi-Very bright deep purple, velvety appearance, large spike.

*Lord Rayleigh-Dark violet, purple centre, blue effect.

*Lumineux-Pure light red, shaded lighter toward centre, bright crimson eye, very large flower.

*Mars-Le-Tour-Large flower, clear pink, almost half of each petal white. $2 \frac{1}{2}$ inch pots.

Meteore-Rose, white centre.

*Montagnard-Bright dark crimson, dark centre, large fine spike.

*Pink Beauty-Pale pink, enormous spike.

*R. P. Struthers-Light crimson pink, slightly tinted orange, distinct dark centre, very fine.

Richepin-Pure white, very large crimson centre, covering nearly half the flower. $2 \mathrm{~T} / 2$ inch pots.

William Ramsay-Deep purple magenta, darker centre, bright velvety appearance. 


\section{DWARF. I 8 INCHES to 2 FEET.}

Albatre-Pure white, large flower.

*Atala-Clear dark pink, light centre

*Candeur-Pure white, very dwarf, good-sized flower and spike.

Dolly-Pale pink, lighter eye. $2 \frac{1}{2}$ inch pots.

E. Danzervilliers-Lilac, shading to white centre, $2 \frac{1}{2} \mathrm{in}$. pots.

.20

2.00

I. 50

*Esperance-Large flower, magenta lilac shaded to white centre, one of the best.

*Evenement-Bright soft pink, tinted salmon, blue-purple eye.

*Fedora-Large flower, white, suffused with light crimson, shading to crimson centre.

Japonais-Pink, light centre.

Suffrage-Light magenta, crimson centre.

Aurora Borealis-Good-sized flower and spike, light crimson, dark centre.

*Coccinea-Deep, bright red, small flower, but a very large spike.

Cross of Honor-Each petal lilac with wide margins of white. . I 5

Czarina-Pure white, very large pyramidal spike.

Eclaireur-Large flower, deep magenta.

*Gen. Chanzy - Scarlet pink, tinted salmon, very fine spike,

Henry Murger-Large, white flowers, very large crimson centre. $2 \frac{1}{2}$ inch pots.

*Independence-Pure white, large flower and spike.

*Iris-Deep purple magenta, dark crimson centre, very large spike.

Ixion-White, slightly suffused with crimson, crimson centre, very fine large spike.

*James Bennett-Light pink, tinted salmon, large crimson centre.

James Galloway-Bright crimson, maroon centre.

Le Feu Du Monde-Bright reddish pink, dark centre.

*Le Soleil-Bright crimson pink, shaded lighter toward centre.

Le Vaughan-Pale magenta lilac, pink centre.

Matador-Similar to General Chanzy, smaller flowers, but larger spike.

*Mme. Meuret-Similar to Le Feu du Monde, earlier flowering.

*Mme. P. Langier-Bright pink, shaded salmon, crimson centre, fine spike.

*Saisons Lierval-Pure white, distinct crimson eye, very fine. $2 \frac{1}{2}$ in. pots. 


\section{PHLOX DECUSSATA-“CHAMPION."”}

A new dwarf, large flowering variety, beautiful clear pink, with large white center. I $1 / 2-2$ feet.

\section{PHLOX DECUSSATA- "DAWN."}

Another new variety, of a delicate shade of pale pink. Goodsized flower and spike. From $2 \frac{1}{2}$ inch pots.

\section{PHLOX SUFFRUTICOSA.}

Early Flowering Phlox, similar to Phlox decussata, but coming into flower in June and lasting through the summer. The foliage is long and narrow and the spikes I to 2 feet in height. The following varieties are among the best grown.

Burns-Rosy purple.

Beauty of Mindon-White ground, flushed with deep rose. .I 5

Miss Lingard-Large spikes of white, suffused with pink. .I 5

Modesty-Large flowers, lilac pink.

Progress-White, suffused with lilac.

\section{PHLOX SUFFRUTICOSA-"MONT BLANC."}

A new and very fine pure white variety.

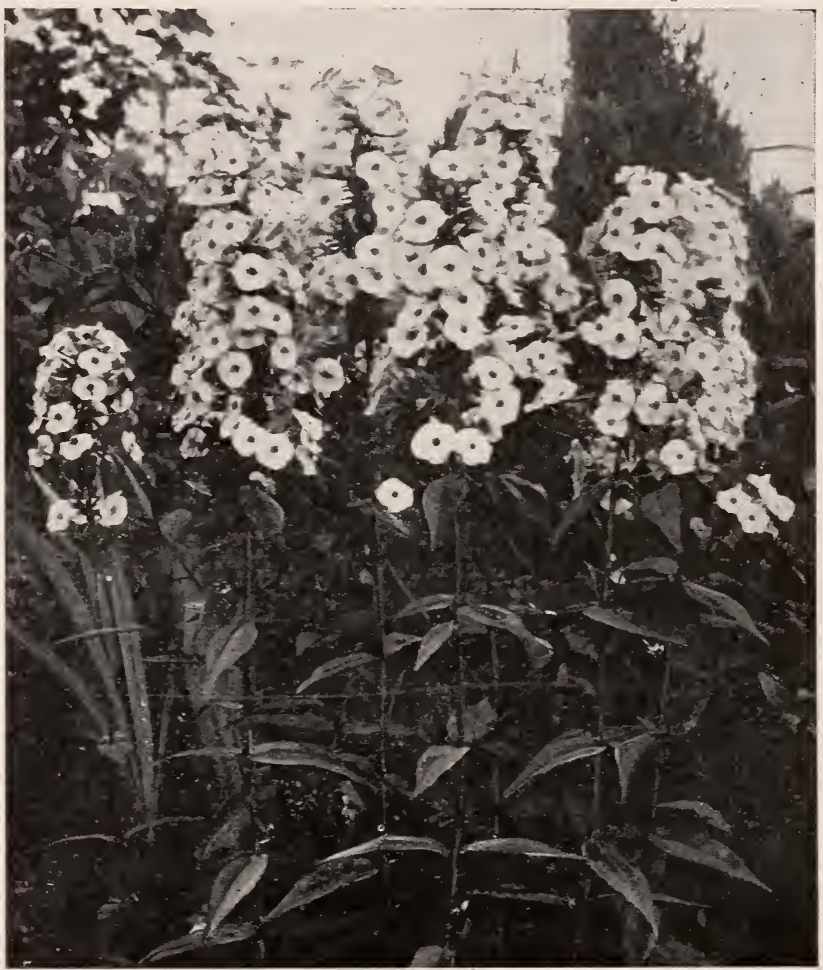




\section{General Collection}

An index will be found on page $4 \mathbf{2}$, giving the Common Names of the Hardy Flowers offered in this catalogue.

Special prices per roo on application. Certificate of inspection accompanies each shipment.

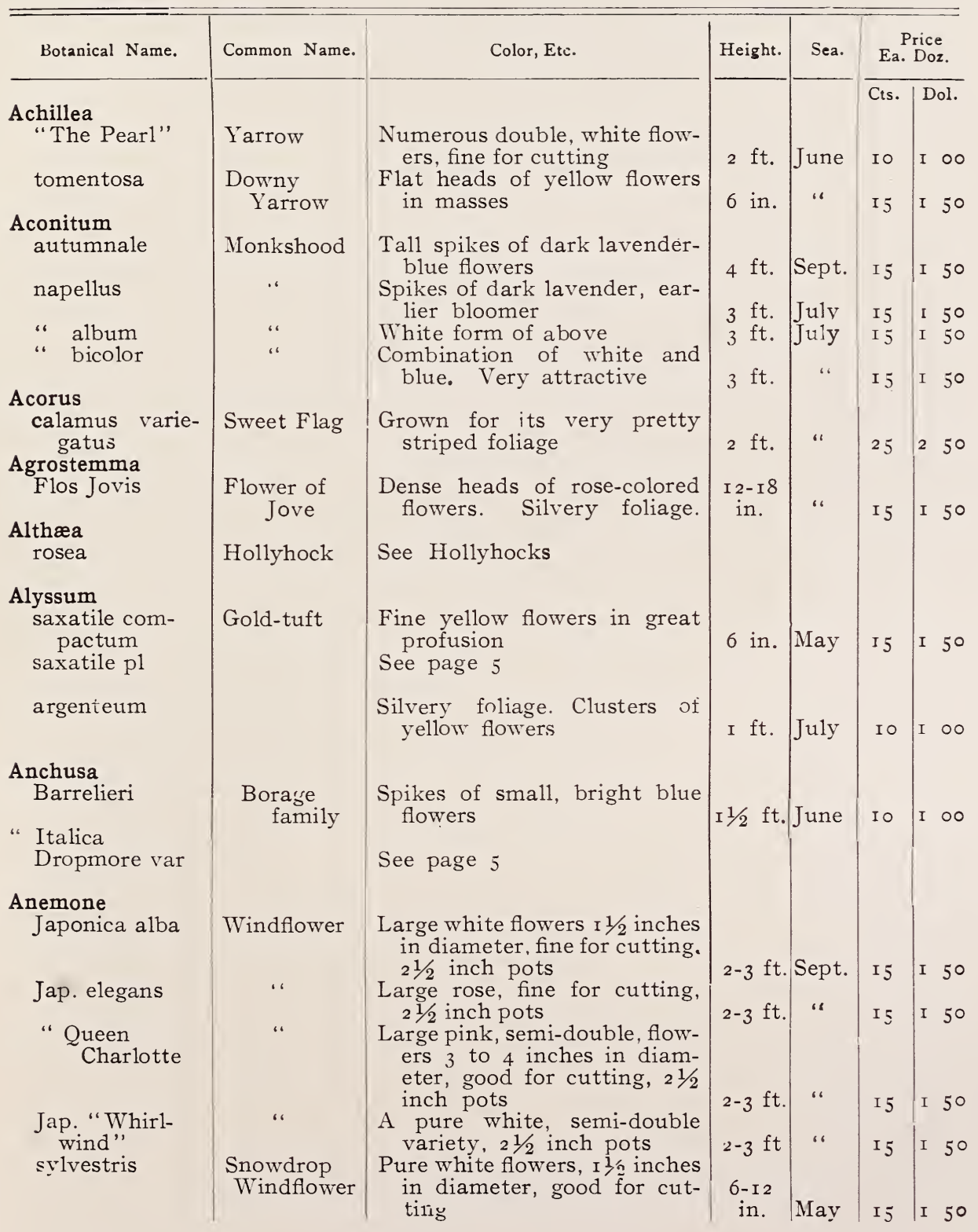




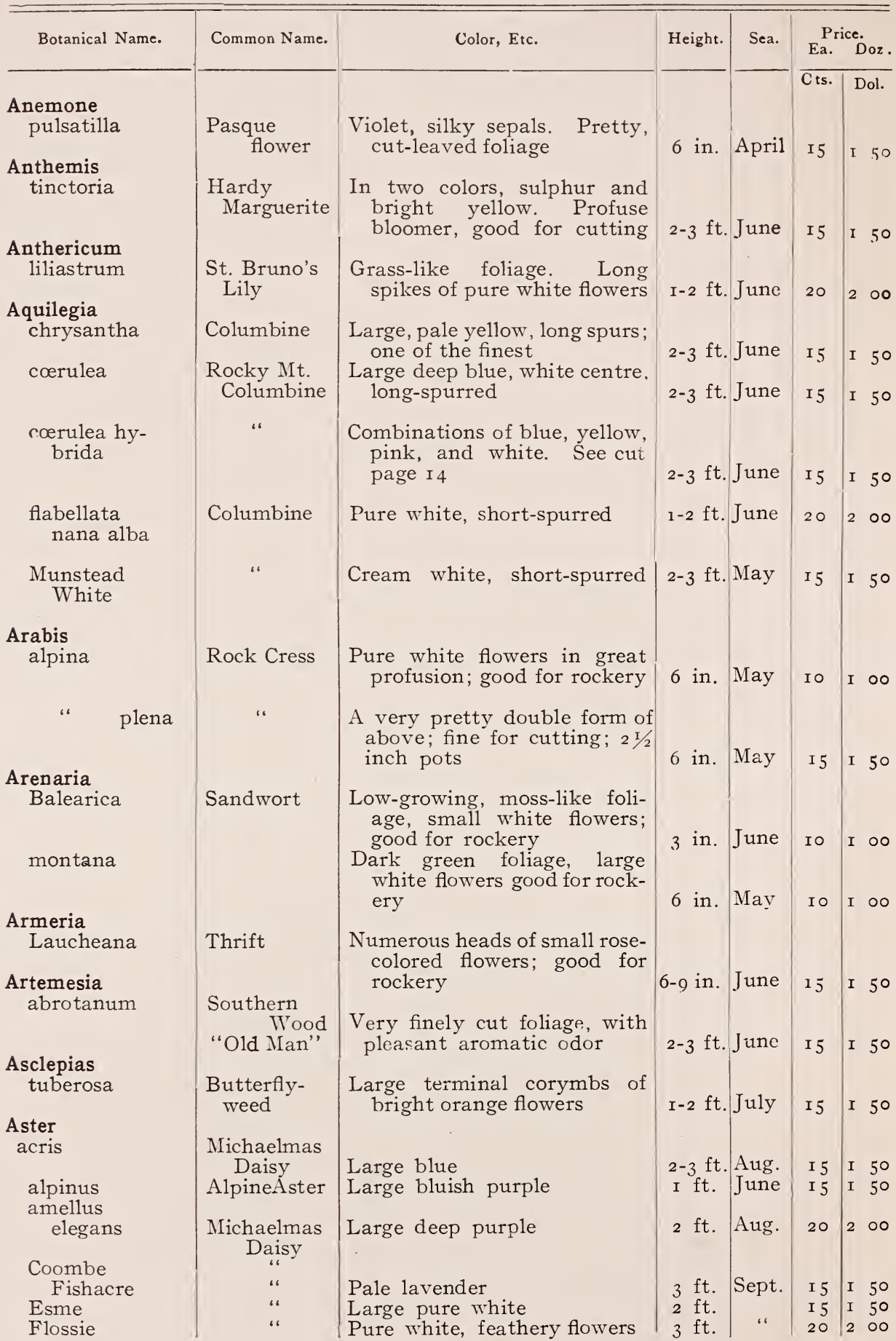




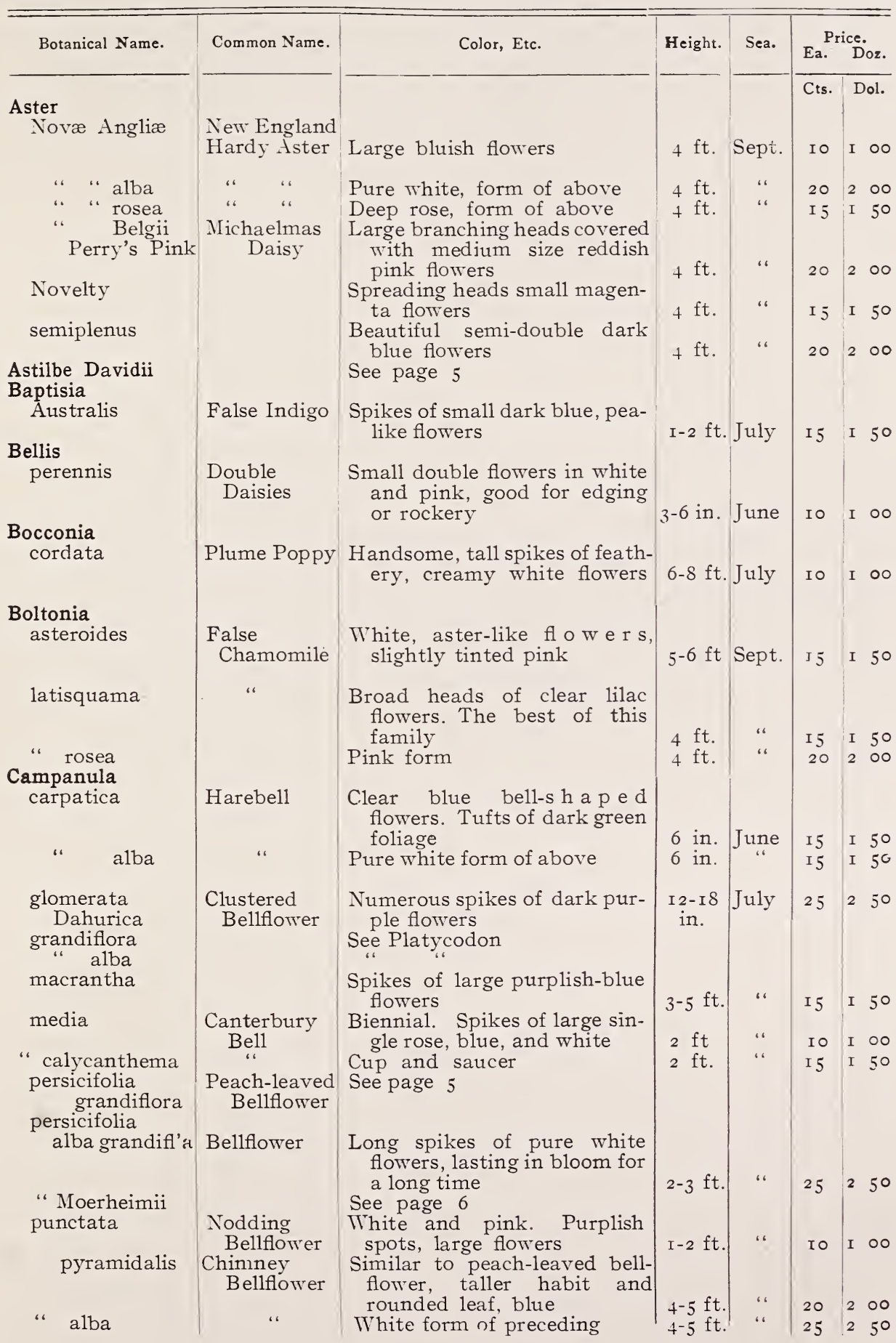




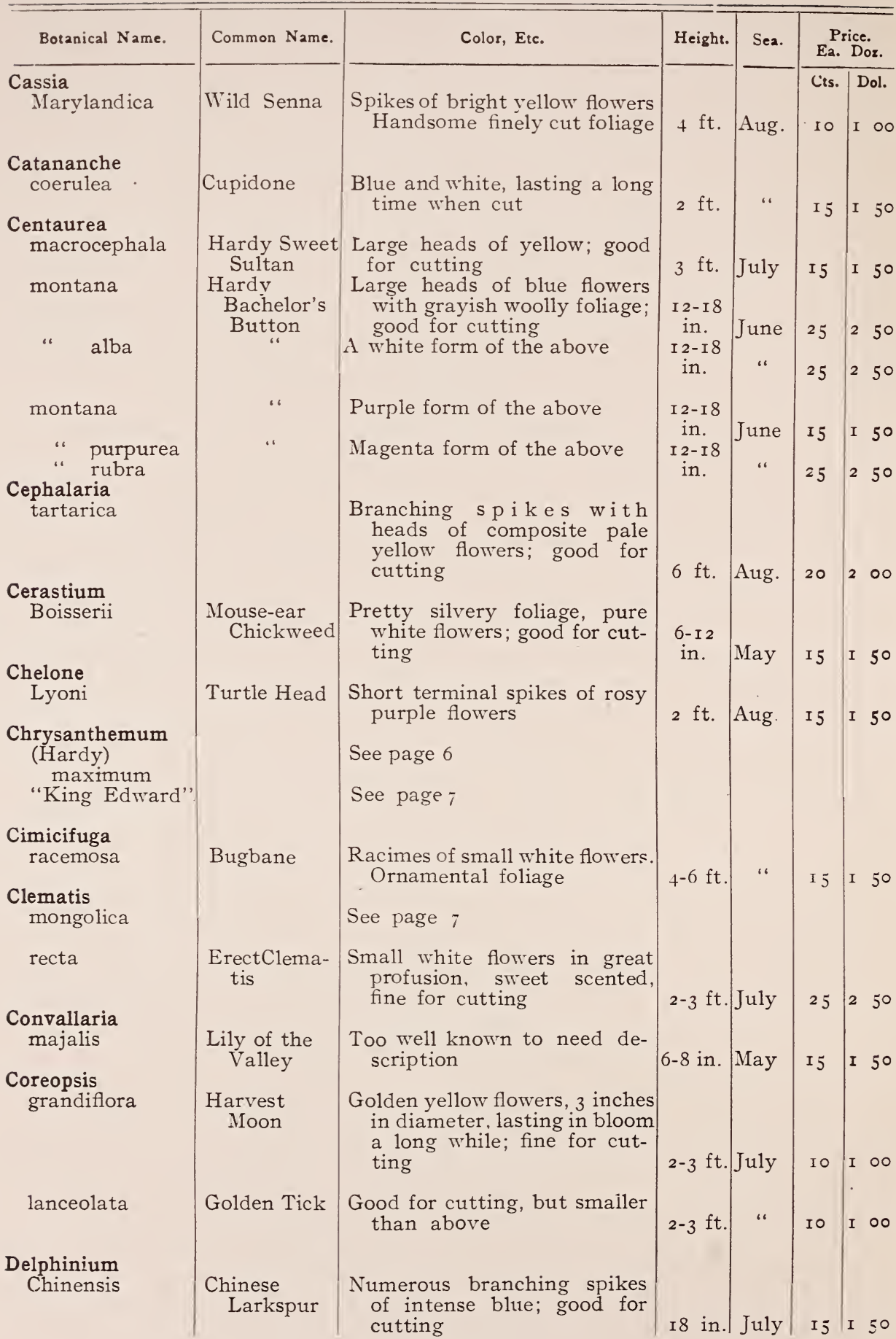




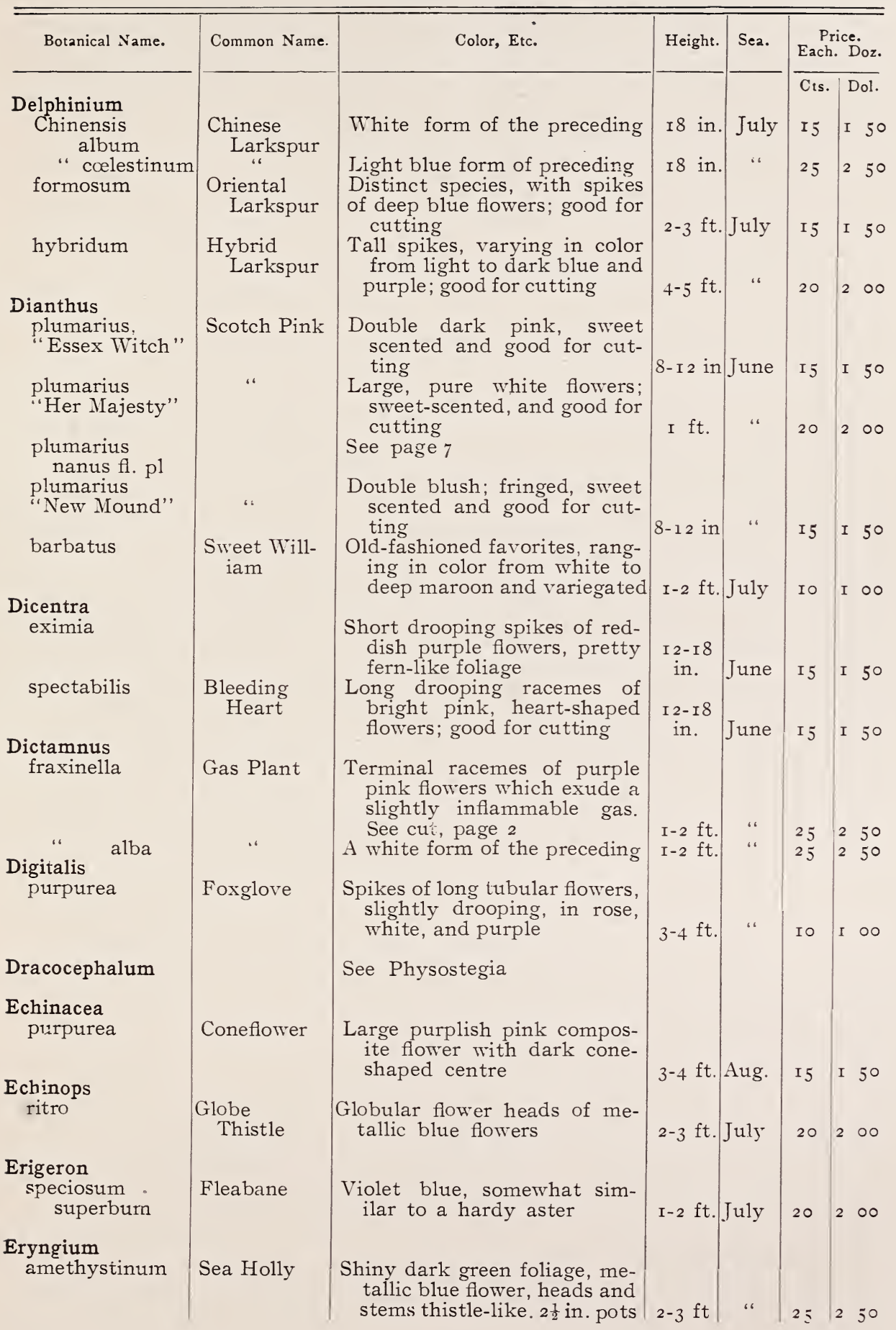


Botanical Name.

\section{Eulalia}

gracillima

univittata

japonica

variegata

japonica zebrina

Euphorbia

corrollata

\section{Funkia}

ovata

subcordata

undulata picta

\section{Gaillardia}

grandiflora

\section{Galium}

boreale

\section{Galtonia}

candicans

(Hyacinthus)

\section{Geranium}

ibericum

sanguineum

“ album

\section{GeumHeldreichi} splendens

\section{Gillenia}

trifoliata

\section{Gypsophila \\ acutifolia}

paniculata

repens plena

(n)

Common Name.

Ornamental Grass

Ornamental Grass

Zebra Grass

Flowering Spurge

Plantain Lily

Ornamental foliage, spikes of bluish flowers

Tall green foliage with feathery plumes, lasting in beauty through the winter, if cut early

Similar to preceding, with variegated leaf

Similar to preceding, with leaf striped laterally

Small pure white flowers in abundance; good for cutting

Yellowish green foliage, pure white flowers; good for cutting

Foliage variegated with white

Blanket

Flower

Bedstraw

Giant Summer Hyacinth

Cranesbill

،

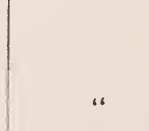




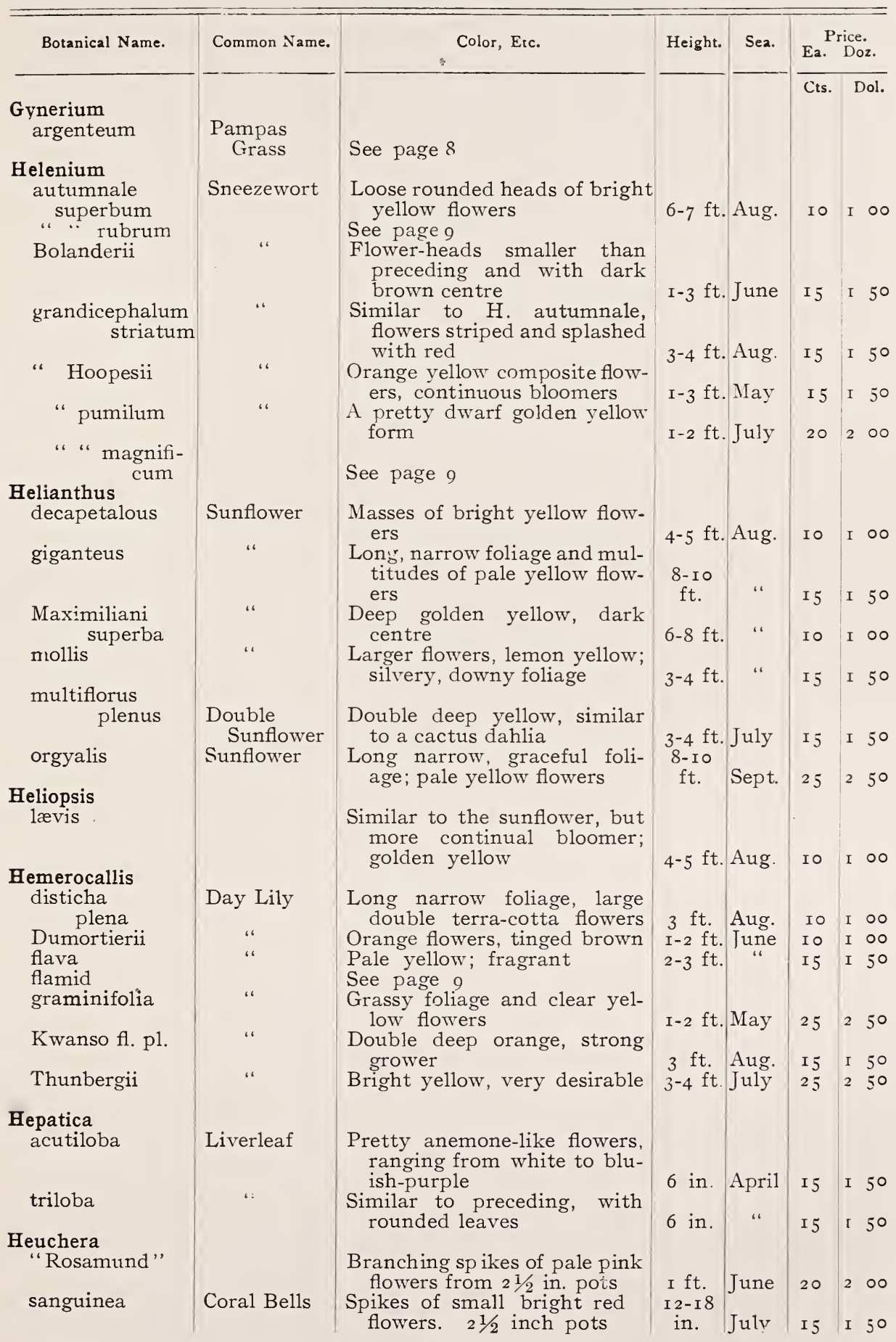




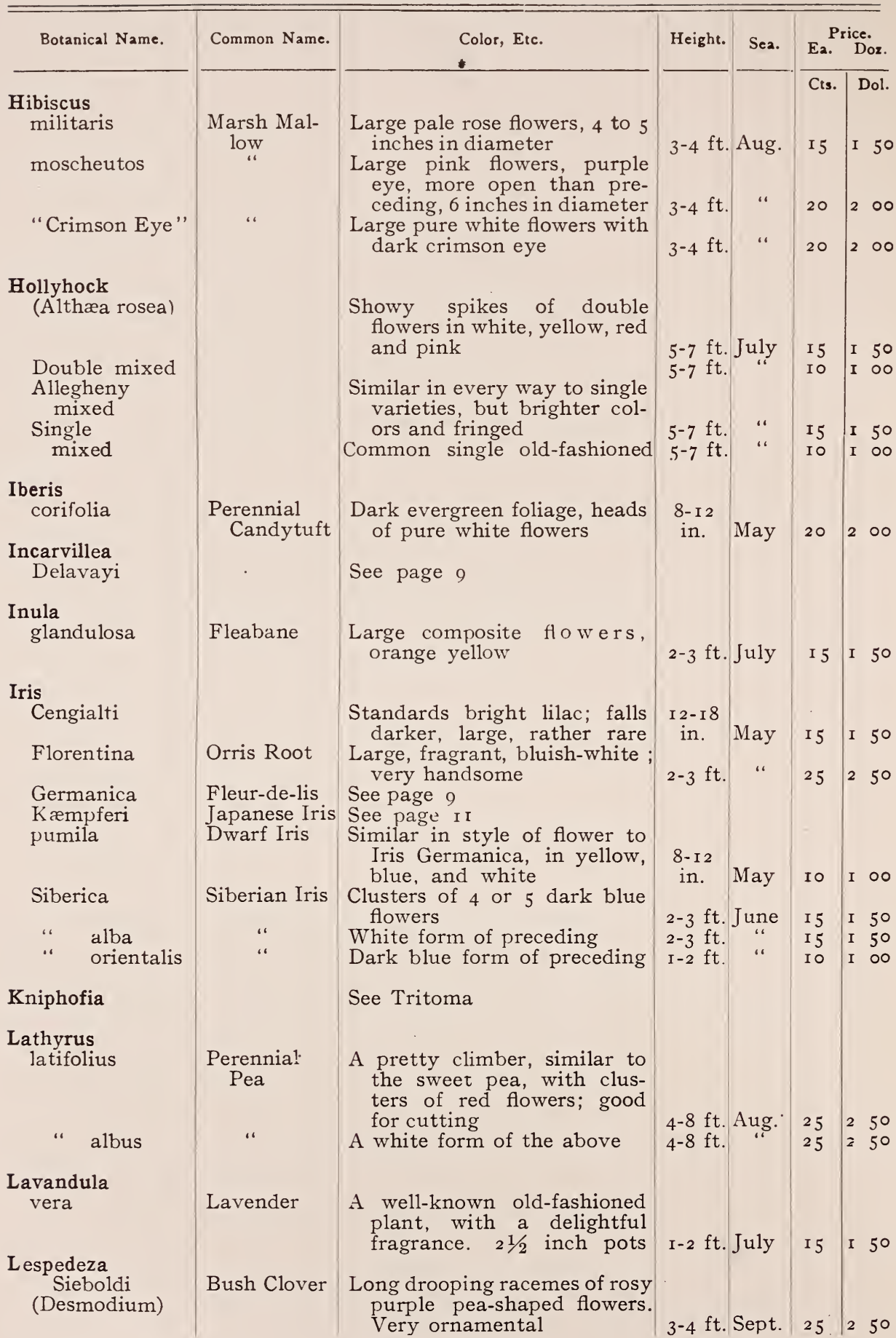




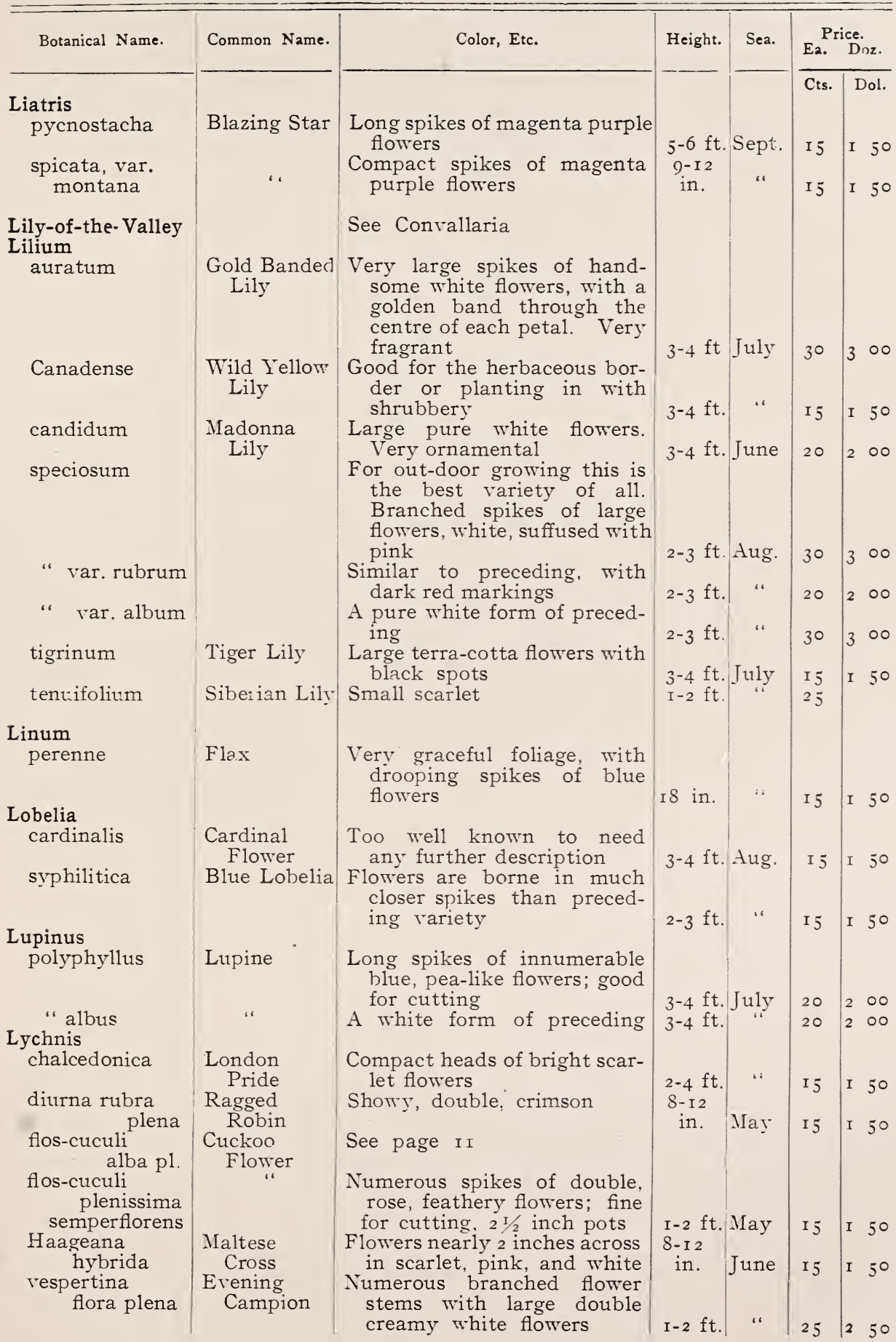




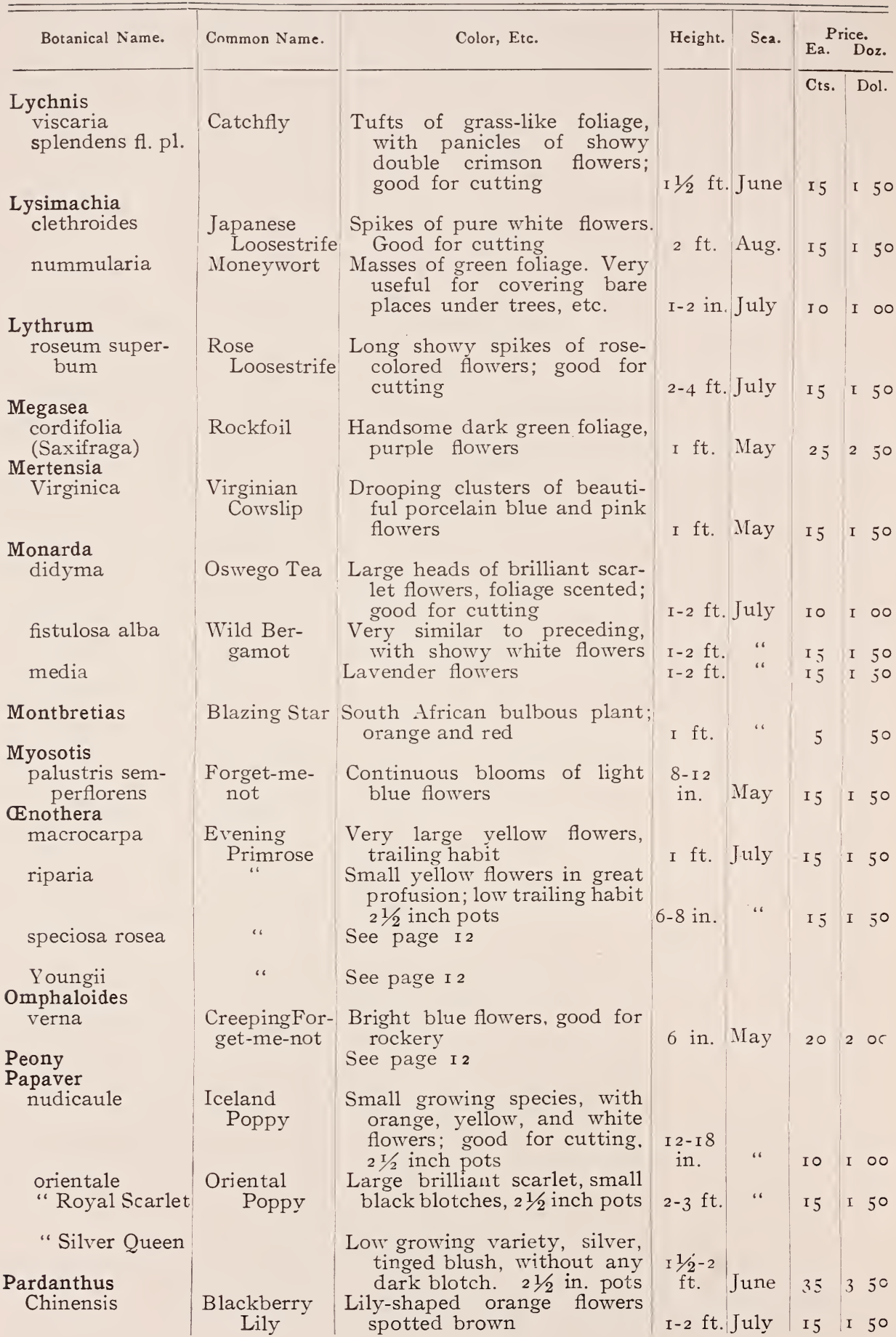




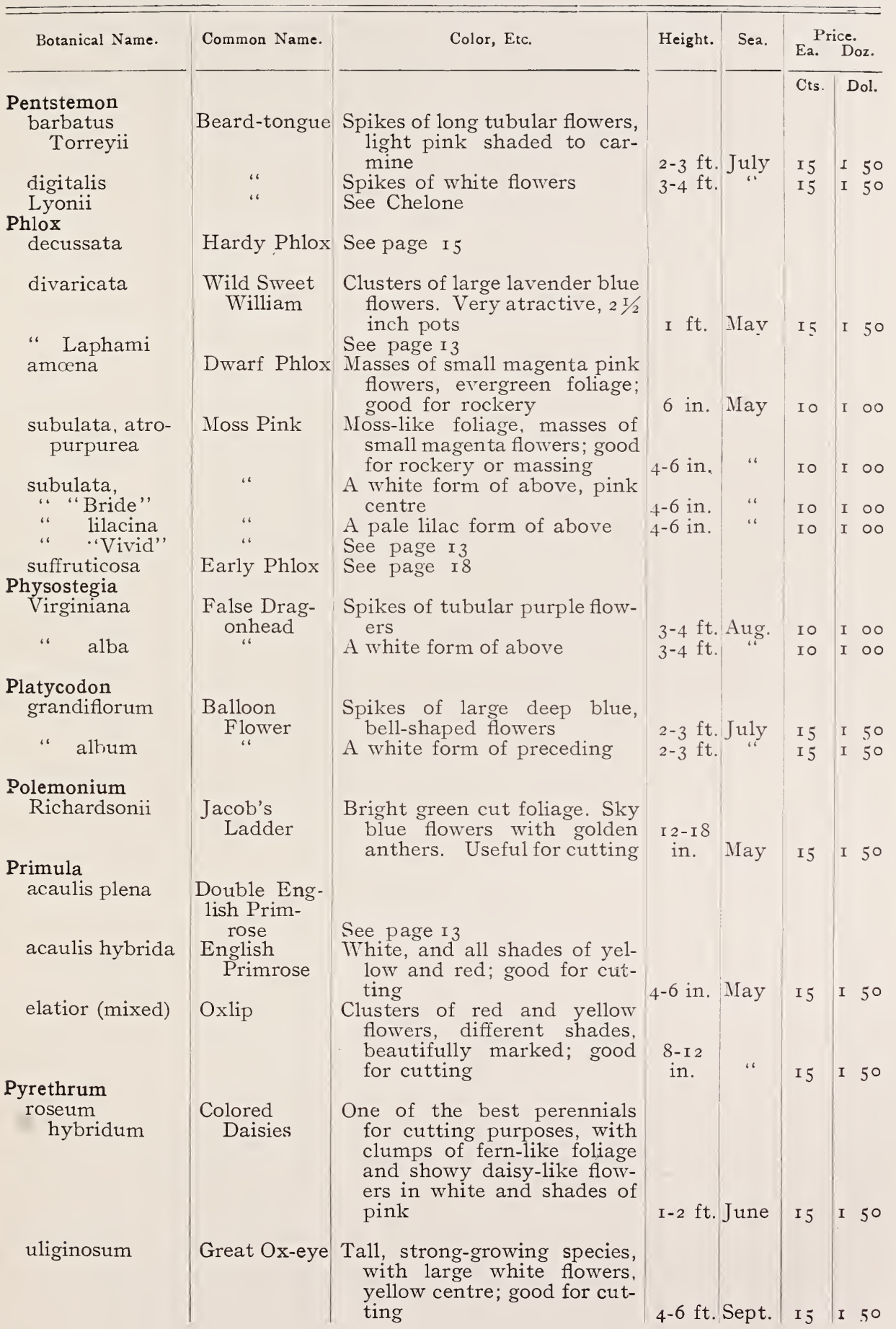




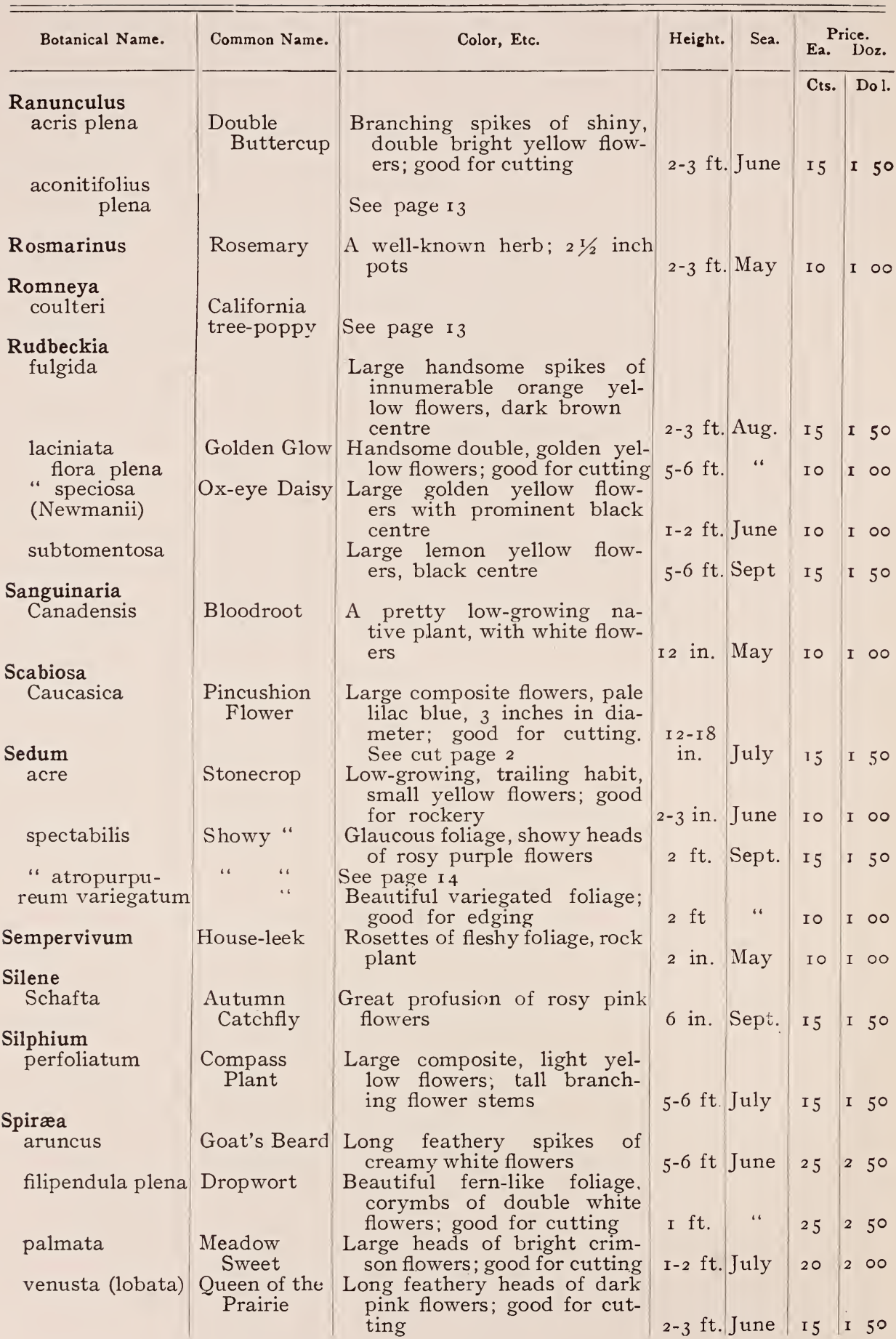




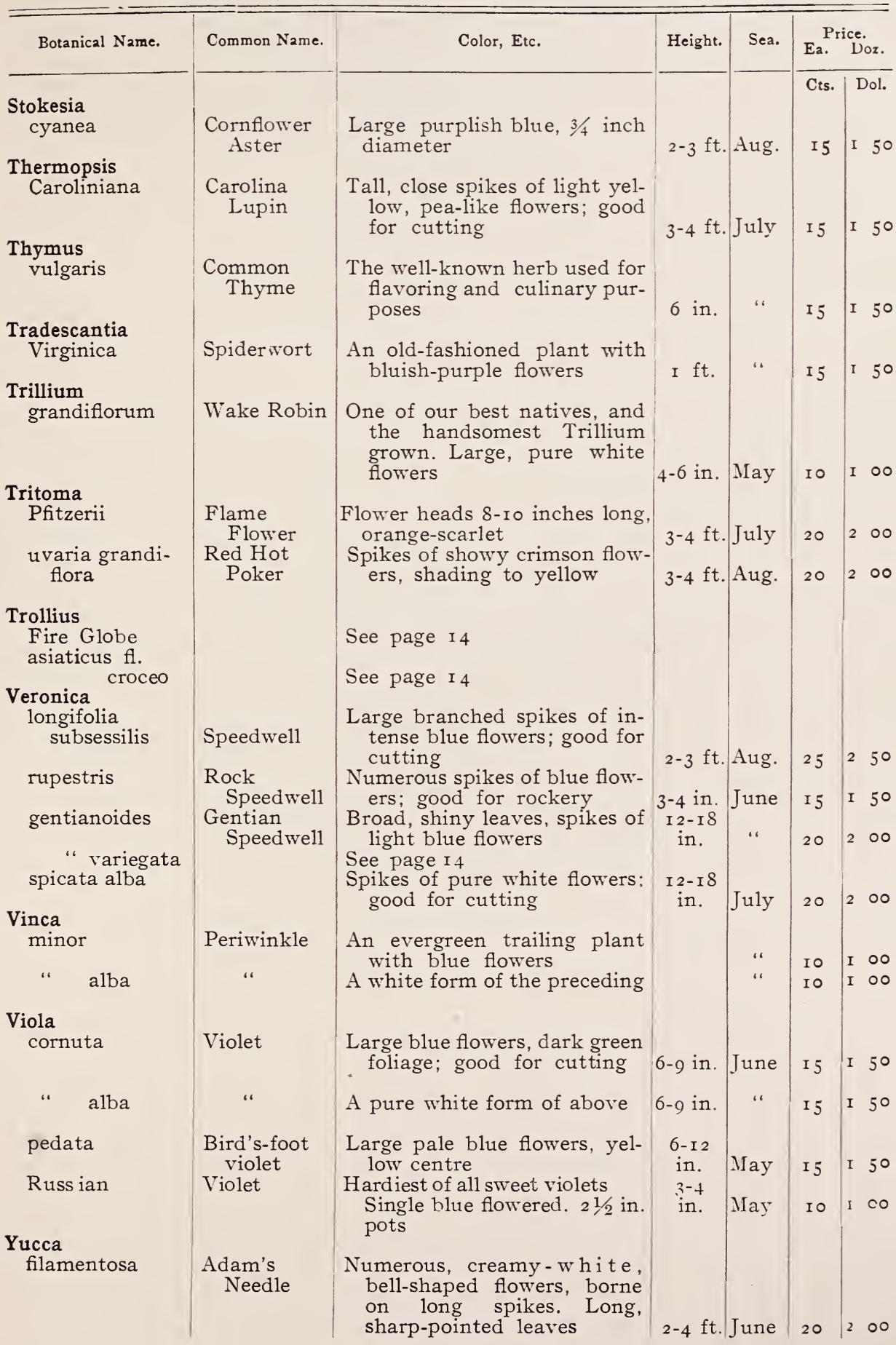




\section{ROS ES.}

\section{LADY GAY.}

A new, hardy climbing rose of great beauty; a strong Each. Dozen. healthy grower and a profuse bloomer. The flowers are a beautiful deep pink, which are borne in large bunches. Ground plants.

\section{DOROTHY PERKINS.}

Large clusters of double, clear shell pink flowers. The foliage is deep green, and the flowers are of large size, fragrant, and borne in fine clusters; a very popular climbing or trailing rose.

\section{THE FARQUHAR ROSE.}

A strong, vigorous grower, with handsome, glossy foliage, and clusters of large, double, pink flowers, of a very pleasing shade.

\section{RUBY KING.}

The largest flowered of the Wichuriania hybrids. Blooms during the month of July in bunches of from 3-10 flowers. Bright, clear pink, beautifully shaded, very sweet-scented, strong grower, good foliage, much admired at Massachusetts Horticultural Society shows. $2 \frac{1}{2}$ inch pots.

\section{NEW ROSE-BABY RAMBLER.}

The latest novelty in hardy roses, which is said to bloom from June till September. The color is identical with the popular Crimson Rambler, .but its distinction is in its dwarf habit and perpetual blooming. An excellent plant, either for bedding or pot culture and forcing. Height, $2-2 \frac{1}{2}$ feet. Ground plants.

FRAU KARL DRUSCHKI-SNOW QUEEN.

The finest Hardy Hybrid Perpetual grown. Pure white, large flower, long buds. 


\section{DEBUTANTE.}

This is a new rose, suitable for either climbing or trailing,

with clusters of double, beautiful, soft-pink flowers. $\$ .50$

\section{SWEETHEART.}

Another new rose, with large, bright-pink, double flowers, changing to white when expanded. Good for either climbing or trailing.

\section{PERSIAN YELLOW.}

A large-growing species, covered with deep golden yellow flowers in June.

\section{HYBRID PERPETUAL ROSES.}

The following varieties of Hardy Roses are among the best for outdoor planting and cutting purposes:

Alfred Colomb-Carmine crimson; large.

American Beauty-Deep crimson; very fragrant.

Baroness Rothschild-Pale pink.

Coquette des Alps-White, centre shaded pink.

General Jacqueminot-Scarlet crimson.

John Hopper-Bright rose; large.

Margaret Dickson-Pure white.

Prince Camille de Rohan-Velvety crimson; deep.

35 cents each; $\$ 3.50$ dozen.

\section{HYBRID TEA ROSES.}

A question generally asked by purchasers is, "Have you a rose that will bloom all summer?" and we answer that La France is an ideal all summer blooming Rose. We mention this variety as it is the most popular garden rose grown, and a "Hybrid Tea."

The varieties offered are the best to be had. The most satisfactory way to winter is to dig them up in the fall and heel in very deeply in a dry position, in fact bury them,- - digging up and replanting about the second week in April. $2 \frac{1}{2}$ in. pots. Ready May r.

Antoine Rivoire-Center salmon flesh, edge of petals creamy white, tinged pink.

Aurora-Bright, deep pink. 
Bessie Brown-Large pure white, very fine.

Duchess of Albany-A lovely shade of deep rose.

Etoile de Lyon-Deep golden yellow.

Greeting of Teplitz-The best for bedding. Bright scarlet shading to velvety crimson.

Helen Gould-Rosy-crimson, long pointed buds.

Helen Gambier-Orange yellow, shading to coppery yellow.

Kaiserin Augusta Victoria-Pure white, large fine buds.

Lady Battersea-Wine red, long budded.

La France-Beautiful silvery rose.

Madame Abel Chatenay-Creamy rose, tinged salmon.

Madame Jules Grolez-Satiny pink, very fine.

Madame Caroline Testout-Satiny rose, extra good.

Meteor-Velvety red.

Mrs. Robert Garrett-Shell pink, deeper in center.

Souvenir de President Carnot-Delicate fawn, center darker.

Triomphe de Pernet Pere-Clear magenta red.

Vicountess Folkestone-Delicately tinted rose.

White La France-Fawn white.

\section{POLYANTHA OR FAIRY ROSES.}

These are very profuse bloomers, and well adapted for bedding purposes, as they flower continually all summer, and they will, if lifted, flower all winter as well, making very desirable house plants. These are sometimes called miniature roses, as the flowers are so very small.

They are perfectly hardy, if suitably protected through the winter.

Clothilde Pfitzer-Pure white.

Each. Dozen.

George Pernet-Very bright rose.

Mlle. Cecile Bruner-Rosy pink.

Marie Pavie-Large clusters, creamy white, flushed carmine.

Mignonette-Clear pink changing to white.

Princess Marie Adelaide-Pink.

Perle d'or-Coppery-gold, very fine.

From $2 \frac{1}{2}$ inch pots. Mav I. 


\section{HARDY CLIMBING ROSES.}

Crimson Rambler -35 and 50 cents each. $\$_{3.50}$ and $\$_{5.00}$

Each. Dozen. dozen. Extra large bushes, $4-5$ feet. .75 each.

Mutiflora Japonica-Blackberry Rose. Clusters of small pure white flowers, covering the entire plant, and somewhat resembling the flowers of a blackberry; fragrant.

Pink Rambler.

Setigera (Prairie Rose)-Single flowers borne in clusters, changing from deep rose to white.

Yellow Rambler.

\section{CHEROKEE ROSE.}

The famous rose of the South, quite hardy. Single flowers, creamy white. From $2 \frac{1}{2}$ inch pots.

\section{TRAILING WICHURIANA ROSES.}

For covering rocks, banks, and other bare spots, there is nothing to equal the cemetery rose. They are both single and double, and range in color from white to deep rose, and shades of yellow.

\section{ROSA RUGOSA.-( JAPANESE ROSE).}

These are very fine for single specimens, beds and hedges. Handsome foliage. Very free and continuous flowering. The flowers are large, single, red, and followed by very large, round berries. Red.

Rosa rugosa alba. White form of preceding.

\section{ROSA RUGOSA, CONRAD FERDINAND MEYER.}

A new hybrid of the popular Japanese rose, a vigorous grower and free bloomer. The flowers are large, perfectly double, deep rose in color, and very fragrant. A good rose for all purposes.

\section{POLYGONUM BALDSCHUANICUM.}

A new climber, destined to become very popular; especially adapted for poles, trellises, etc. It is covered in summer with graceful sprays of innumerable feathery, white flowers. Fine for cutting. Strong plants. 


\section{CLIMBING VINES.}

Ampelopsis Quinquefolia-Common Woodbine.

Ampelopsis Veitchii-Boston or Japanese Ivy.

Aristolochia Sipho-Dutchman's Pipe. Large, dark-green foliage. A rapid grower when established.

Bignonia Radicans-Trumpet Vine.

Celastrus Scandens-Bitter-sweet.

Clematis Paniculata-A very strong grower and well adapted, on account of its freedom of flowering and fragrance, for piazzas, etc. Panicles of pure white flowers. 35 and 50 cents each.

Clematis Jackmanii-Large, rich purple flowers in great profusion.

Clematis Henryi-Large, pure white.

Lonicera Hallii-Japan Honeysuckle. Very free and fragrant white and yellow flowers.

Wistaria Chinensis-Long clusters of violet purple flowers. $.5^{\circ}$

Wistaria Chinensis Alba-A white form of the above.

\section{AZALEA MOLLIS}

A handsome deciduous shrub, covered in early spring with bunches of flowers similar to Rhododendron; color in shades of red and yellow.

KALMIA LATIFOLIA-(MOUNTAIN LAUREL).

Decidedly one of our best natives. Evergreen foliage, covered in June with clusters of white and pink flowers.

\section{RHODODENDRON HYBRIDUM.}

These should be planted in well sheltered positions, or well protected from the sun through the winter. They bloom the latter part of May. Different shades of color.

\section{RHODODENDRON MAXIMUM.}

The hardiest of all Rhododendrons, growing to a height of 6 to 8 feet. Flowers borne on large trusses, varying in color from white to light pink. They do well in any situation, but are especially adapted to shade and moist places. Flowers borne in July after the hybrid varieties are over. $\$ 2.00, \$ 5.00$ each, according to size. 


\section{JAPANESE BLOOD-LEAVED MAPLE.}

A low-growing, spreading bush with handsome, very much Each. Dozen. cut foliage of the deepest blood red, which keeps its color from May till cut off by frost. This is undoubtedly one of the handsomest shrubs grown, and quite hardy.

\section{HARDY EVERGREENS. CONIFERS.}

Abies alba-White spruce. Hedges, wind breaks or specimens. Plants $2 \frac{1}{2}$ feet high.

Abies Balsamea. Balsam fir. Wind breaks or specimens. Plants 2-2 $1 / 2$ feet high.

Abies Concolor-Silver fir. Fine for specimens. Plants 2 feet high.

Abies Douglasi-Douglas fir. Wind breaks or specimens. Plants 2-2 $\mathrm{T} / 2$ feet high.

Abies Excelsa-Norway Spruce. Hedges or wind breaks. Plants $2-2 \frac{1}{2}$ feet.

Picea Pungens-Colorado spruce. Green variety. Wind breaks or specimens. Plants 2 feet high.

Picea Pungens glauca-Blue spruce. For specimens. Plants 2 feet high.

Picea Pungens glauca var Kosteri-Blue spruce, and the bluest of all. Plants $\mathrm{I} / 2$ feet high.

Pinus Strobus-White pine. Hedges, specimens, or wind breaks. Plants $4-5$ feet high.

I. 50

\section{CACTUS DAHLIAS.}

This type of dahlia, with its irregular, graceful blooms, of many exquisite varieties, bears little resemblance to the heavy, ball-shaped flowers, formerly so much in vogue. The following is a selection of fieldgrown roots of carefully chosen sorts:

Amos Perry-Brilliant red, large and showy.

Dainty-An exquisite blend of lemon, yellow and clear pink.

Florodora-Wine crimson. Distinct in color.

Each.

$\$ .50$

Galliard-Deep red and one of the best.

Golden Queen-Bright yellow and distinct. $\quad .50$

Mr. Seagrave-Violet pink, with center almost white. .20

Mr. Seagrave-Violet purple. Exquisite form.

M. Florent Pauwels-Light salmon. Fine large flowers. .75 
Mrs. D. B. Crane-White. Exquisitely perfect in form

\author{
and color.
}

Mrs. Mortimer-Soft red. A typical cactus dahlia, much incurved.

Prince of Orange-Yellow, shading to orange. Very free.

Uncle Tom-Dark crimson maroon, almost black.

No substitutions will be made unless expressly authorized. Should stock be exhausted, the above varieties can be replaced with others just as good or better.

Splendid cactus varieties (our selection), \$2.00 per dozen.

The new pink decorative dahlia, Jeanne Charmet, has exquisite flowers of large size, sometimes 8 inches across, with long, wiry stems. Stock limited. Price, \$r.oo each.

Dahlia roots should not be planted until the last of May, and should be lifted in the autumn after the first killing frost and stored in a dry cellar.

\title{
STRAWBERRY PLANTS.
}

Layer plants for spring planting. Delivery during April and May. For fall planting after September I. All the leading varieties. \$I.00 per one hundred.

Pot grown plants, for summer and early fall planting, well rooted from $2 \mathrm{I} / 2$ inch pots. Delivery July I 5 to September I. All the leading varieties. $\$ 2.50$ per hundred. $\$ 20.00$ per thousand.

Texas-...A new variety. Ripens two weeks in advance of Marshall. Very sweet. Color, light red; very productive. Resembles the Marshall in shape. Forcing plants only.

Forcing plants of Marshall and Texas, from 4 inch pots. Ready for delivery aiter September I 5. \$10.00 per hundred.

\section{BLACKBERRIES.}

Agawam. Dozen, $\$ .50$. Per hundred, $\$ 3.00$.

\section{RASPBERRIES.}

Cuthbert and Golden Queen. Dozen, $\$ .50$. Per hundred, \$3.0c. 


\section{Hardy Ornamental Shrubs.}

The best and proper time of year to plant shrubs is from the ist of October till hard frost, and from the ist of April to about the 15 th of May.

The height given is that of maturity.

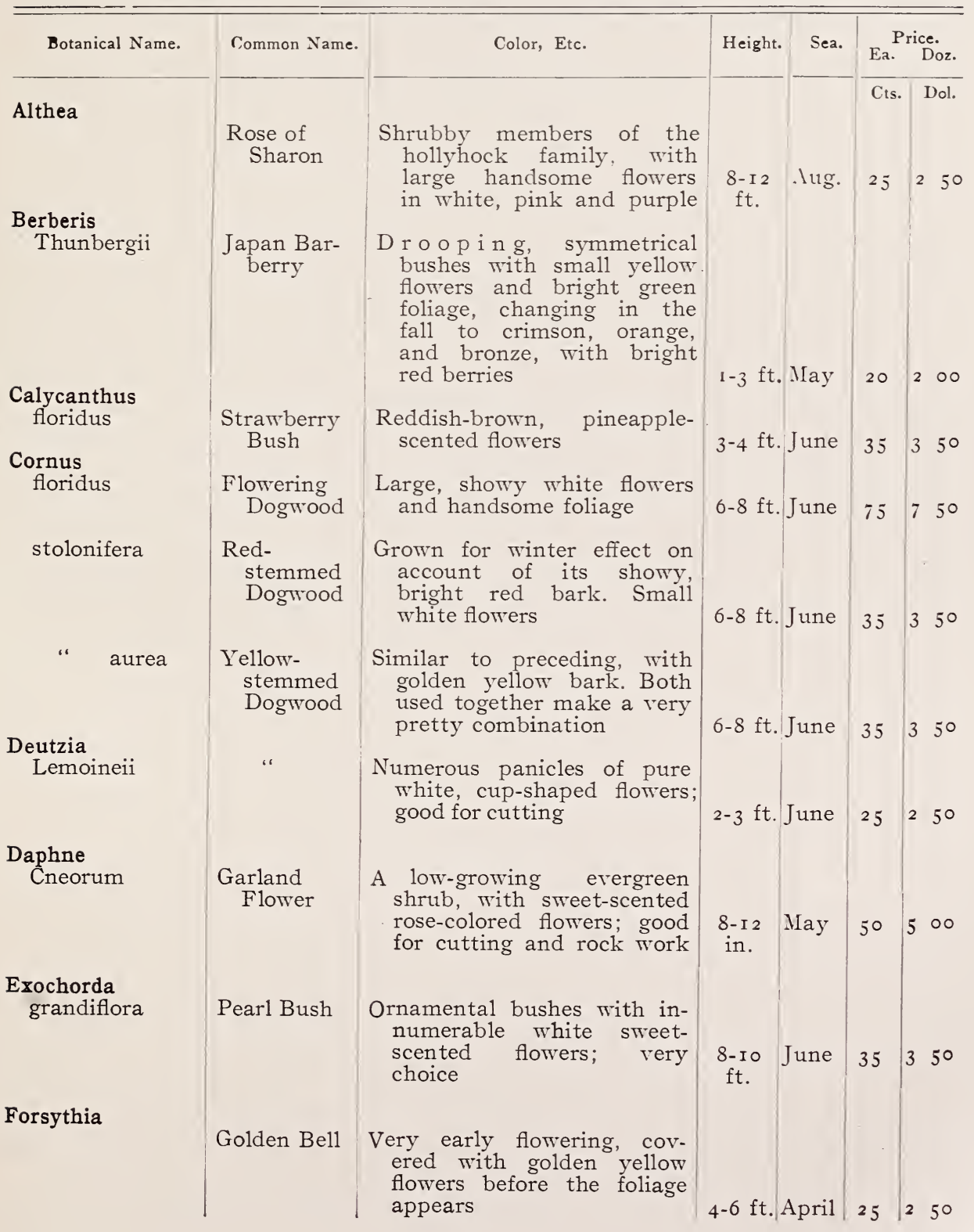




\begin{tabular}{|c|c|c|c|c|c|c|}
\hline Botanical Name. & Common Name. & Color, Etc. & Height. & Sea. & $\begin{array}{l}\text { Pri } \\
\text { Ea. }\end{array}$ & $\begin{array}{l}\text { rice. } \\
\text { Doz. }\end{array}$ \\
\hline $\begin{array}{l}\text { Hydrangea } \\
\text { paniculata } \\
\text { grandiflora }\end{array}$ & $\begin{array}{l}\text { Hardy } \\
\text { Hydrangea }\end{array}$ & $\begin{array}{l}\text { Large symmetrical bushes } \\
\text { with enormous panicles of } \\
\text { white flowers, changing to } \\
\text { deep rose in the fall }\end{array}$ & $4-5 \mathrm{ft}$. & Aug. & Cts. & 350 \\
\hline $\begin{array}{l}\text { Kerria } \\
\text { japonica } \\
\text { variegata }\end{array}$ & & $\begin{array}{l}\text { Numerous small yellow flow- } \\
\text { ers, foliage handsomely } \\
\text { variegated with silver }\end{array}$ & $\mathrm{I}-2 \mathrm{ft}$ & Iune & & \\
\hline $\begin{array}{l}\text { Lilac } \\
\quad \text { (Syringa) }\end{array}$ & Lilac & Common purple variety & $\begin{array}{l}8-\mathrm{ro} \\
\mathrm{ft} .\end{array}$ & May & $\begin{array}{l}25 \\
25\end{array}$ & $\begin{array}{ll}2 & 50 \\
2 & 50\end{array}$ \\
\hline “، & “ & Common white variety & $\begin{array}{l}8-10 \\
\mathrm{ft} .\end{array}$ & . & 35 & 350 \\
\hline $\begin{array}{l}\text { Lonicera } \\
\text { Tartarica }\end{array}$ & $\begin{array}{l}\text { Shrub } \\
\text { Honey- } \\
\text { suckle }\end{array}$ & $\begin{array}{l}\text { A well-known shrub with } \\
\text { quantities of small pink } \\
\text { flowers }\end{array}$ & $4-5 \mathrm{ft}$. & June & 20 & 200 \\
\hline “ alba & “ & A white variety of preceding & $4-5 \mathrm{ft}$. & “، & 20 & 200 \\
\hline $\begin{array}{r}\text { Philadelphus } \\
\text { coronarius }\end{array}$ & Mock Orange & $\begin{array}{l}\text { Cream white, fragrant flow- } \\
\text { ers }\end{array}$ & $\begin{array}{l}6-\mathrm{ro} \\
\mathrm{ft} .\end{array}$ & “" & 20 & 200 \\
\hline grandiflora & “ & A large flowered variety & $6-8 \mathrm{ft}$ & “" & 20 & 200 \\
\hline $\begin{array}{l}\text { Prunus } \\
\text { Pissardii }\end{array}$ & $\begin{array}{l}\text { Purple- } \\
\text { leaved } \\
\text { Plun }\end{array}$ & $\begin{array}{l}\text { Grown for its bright purple } \\
\text { foliage, and covered early } \\
\text { in the spring with small } \\
\text { purplish-white flowers }\end{array}$ & $\begin{array}{l}8-\mathrm{I}_{2} \\
\mathrm{ft} .\end{array}$ & May & 35 & 350 \\
\hline sinensis alba $p 1$ & $\begin{array}{l}\text { Double } \\
\text { Almond }\end{array}$ & $\begin{array}{l}\text { Branches covered with double } \\
\text { white flowers }\end{array}$ & $3-4 \mathrm{ft}$ & .. & 35 & 350 \\
\hline “ rosea pl. & ، & $\begin{array}{l}\text { A double pink variety of pre- } \\
\text { ceding }\end{array}$ & $3-4 \mathrm{ft}$ & “ & 35 & 350 \\
\hline California & & $\begin{array}{l}\text { A popular shrub for hedges } \\
\text { with dark green oval- } \\
\text { shaped foliage. \$ro and } \\
\text { \$12 per hundred }\end{array}$ & & & I 5 & I 50 \\
\hline $\begin{array}{l}\text { Pyrus } \\
\text { japonicus }\end{array}$ & $\begin{array}{l}\text { Japan } \\
\text { Quince }\end{array}$ & $\begin{array}{l}\text { A very pretty shrub with } \\
\text { an abundance of bright } \\
\text { red flowers; also good for } \\
\text { hedges }\end{array}$ & $6-8 \mathrm{ft}$. & “ & 25 & 250 \\
\hline glabra laciniata & $\begin{array}{l}\text { Cut-leaved } \\
\text { Sumach }\end{array}$ & $\begin{array}{l}\text { Handsome cut-leaved variety } \\
\text { of common Sumach }\end{array}$ & $3-4 \mathrm{ft}$ & July & 35 & 350 \\
\hline $\begin{array}{l}\text { Rhus typhina } \\
\text { laciniata }\end{array}$ & $\begin{array}{l}\text { Cut-leaved } \\
\text { Stag-horn } \\
\text { Sumach }\end{array}$ & $\begin{array}{l}\text { A decided improvement. in } \\
\text { that the foliage is more } \\
\text { deeply cut than any other } \\
\text { variety, very ornamental }\end{array}$ & $8-\mathrm{I} 5 \mathrm{ft}$. & Sept. & 25 & \\
\hline
\end{tabular}




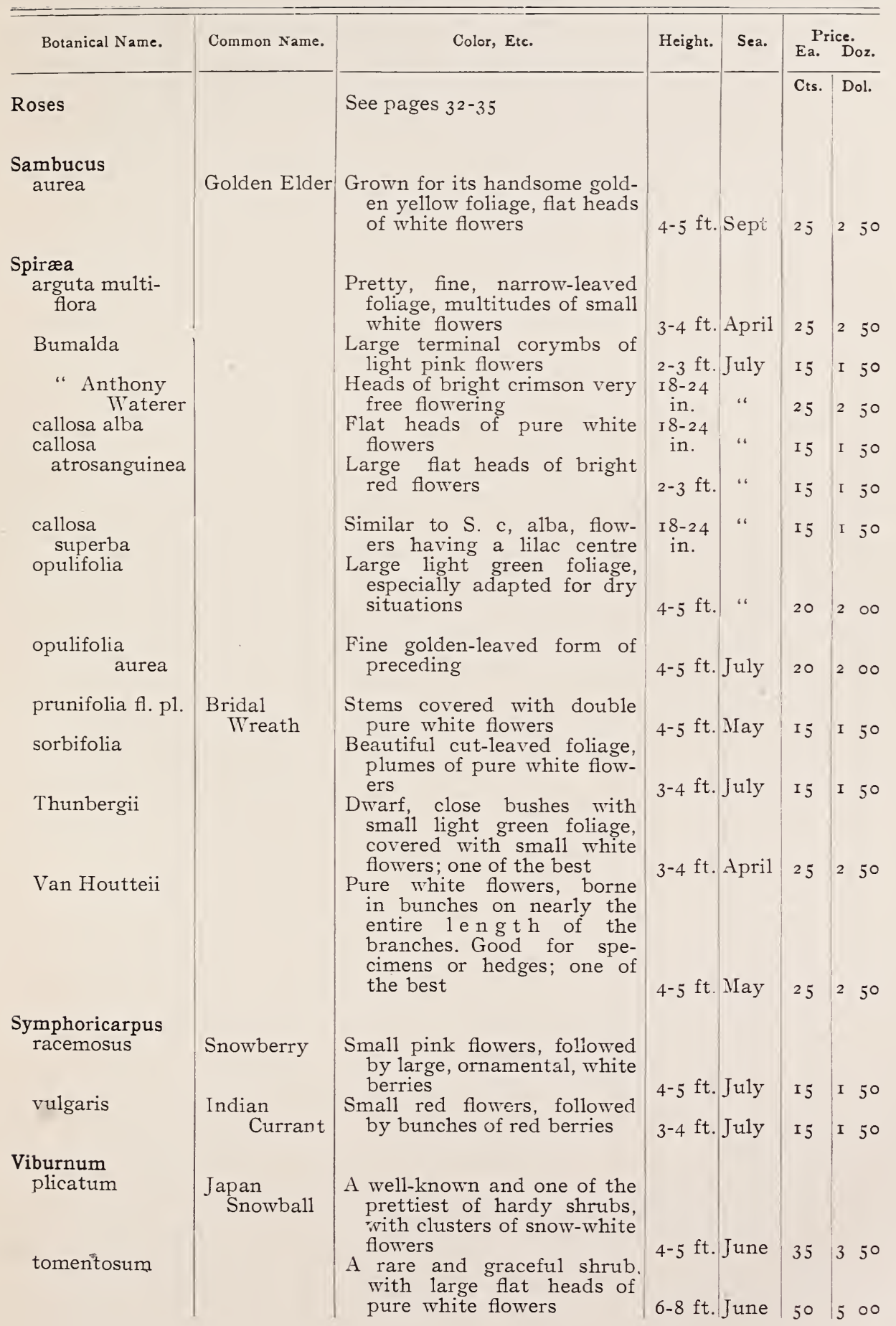




\section{N D E X.}

\section{COMMON NAME}

Adam's Needle

Autumn Catchfly

Baby's Breath

Balloon Flower

Bachelor's Button

Beard Tongue

Bedstraw

Bellflower

Bergamot

Blackbetry Lily

Blanket Flower

Blazing Star

Bleeding Heart

Bloodroot

Blue Cupidone

Blue Lobelia

Borage

Bowman's Root

Bugbane

Bush Clover

Buttercup, Double

Butterfly Weed

California Tree Poppy

Candytuft

Canterbury Bell

Cardinal Flower

Carolina Lupin

Catchfly

Chrysanthemums

Clematis

Columbine

Colored Daisies

Compass Plant

Cone Flower

Coral Bells

Cornflower Aster

Cranesbill

Cuckoo Flower

Day Lily

Dropwort

English Daisies, Double

English Primrose

Evening Campion

Evening Primrose

Fair Maids of France

False Chamomile

False Dragonhead

False Indigo

Flax

Fleabane

Fleur-de-Lis

Flower of Jove

Flowering Spurge

Forget-me-not

Forget-me-not, Creeping

Foxglove

Gas Plant

Globe Flower

Globe Thistle
BOTANICAL NAME Page

Yucca filamentosa 3 I

Silene Schafta 30

Gypsophila $2+$

Platycodon 29

Centaurea montana 22

Pentstemon 29

Galium 24

Campanuia persicifolia 2 I

Monarda fistulosa alba $\quad 28$

Pardanthus Chinensis $\quad 28$

Gaillardia 24

Liatris 27

Dicentra spectabilis $\quad 23$

Sanguinaria 20

Catananche 22

Lobelia syphilitica $\quad 27$

Anchusa I9

Gillenia 24

Cimicifuga 22

Lespedeza 26

Ranunculus arris, fl. $111 . \quad 30$

Asclepias tuberosa 20

Romneya coulteri 30

Iberis $\quad 26$

Campanula media 2 I

Lobelia cardinalis $\quad 27$

Thermopsis 31

Lychnis viscaria splendens $\quad 28$

Chrysanthemum 6

Clematis 22

Aquilegia 20

Pyrethrum roseum 29

Silphium perfoliatum 30

Echinacea 23

Heuchera 25

Stokesia 3 I

Geranium 24

Lychnis Flos cuculi 27

Hemerocallis 25

Spiræa filipendula plena 30

Bellis perennis $2 \mathrm{I}$

Primula acaulis 29

Lychnis vespertina plena 27

CEnothera 28

Ranunculus aconitifolius pl. I3

Boltonia $2 \mathrm{I}$

Physostegia 29

Baptisia 2 I

Linum 27

Inula $\quad 26$

Iris Germanica 9

Agrostemma Flos-Jovis I9

Euphorbia $\quad 24$

Myosotis 28

Omphaloides $\quad 28$

Digitalis 23

Dictamnus 23

Trollius 3 I

Echinops ritro 23 
INDEX-Continued.

\section{COMMON NAME}

Goats' Beard

Gold Tuft

Golden Glow

Golden Tick

Grass, Pampas

Grass, Zebra

Great Ox Eye

Harebell

Harvest Moon

Hollyhock

Houseleek

Iris

Jacob's Ladder

Larkspur, Chinese

Larkspur, Hybrid

Larkspur, Oriental

Lavender

Lily, Gold Banded

Lily, Madonna

Lily, Tiger

Lily-oi-the-Valley

Liverleaf

London Pride

Loosestrife

Loosestrife, Rose

Lupin

Maltese Cross

Marguerite

Marsh Mallow

Meadow Sweet

Michælmas Daisies

Moneywort

Monkshood

Moss Pink

Mouse-Ear Chickweed

Orris Root.

Oswego Tea

Oxeye Dajsy

Oxlip

Pasque Flower

Pea, Perennial

Peony

Periwinkle

Pincushion Flower

Pinks

Phlox

Plantain Lily

Plume Poppy

Poppy, Iceland

Poppy, Oriental

Queen of the Prairie

Ragged Robin

Red Hot Poker

Rock Cress

Rosemary

Sandwort

Saxifrage

Sea Holly

Sneezewort

Southernwood

Speedwell
BOTANICAL NAME

Page

Spiræa Aruncus

Alyssum saxatile compactum

Rudbeckia laciniata fl. pl. 30

Coreopsis lanceolata 22

Gynerium argenteum $\delta$

Eulalia zebrina $2+$

Pyrethrum uliginosum 29

Campanula carpatica 2 I

Coreopsis grandiflora 22

Hollyhock 26

Sempervivum 30

Iris 26

Polemonium 29

Delphinium chinensis $\quad 23$

Delphinium hybridum 23

Delphinium formosum 23

Lavandula vera $\quad 26$

Lilium auratum $\quad 27$

Lilium candidum $\quad 27$

Lilium tigrinum 27

Convallaria 22

Hepatica 25

Lychnis chalcedonica $\quad 27$

Lysimachia 28

Lythrum 28

Lupinus $\quad 27$

Lychnis Haageana 27

Anthemis 20

Hibiscus 26

Spiræa palmata 30

Aster 20

Lysimachia nummularia $\quad 28$

Aconitum I9

Phlox subulata 29

Cerastium 22

Iris florentina $\quad 26$

Monarda didyma 28

Rudbeckia speciosa 30

Primula elatior 29

Anemone pulsatilla 20

Lathyrus 26

Peonia I 2

Vinca 3 I

Scabiosa caucasica 30

Dianthus 23

Phlox I5

Funkia 24

Bocconia cordata 2 I

Papaver nudicaule 28

Papaver orientale 28

Spirœa venusta 30

Lychnis diurna pl. $2 \pi$

Tritoma 3 I

Arabis 20

Rosmarinus 30

Arenaria 20

Megasea 28

Eryngium 23

Helenium 25

Artemesia 20

Veronica 3 I 
INDEX-Continued.

\section{COMMON NAME}

Spiderwort

St. Bruno's Lily

Stonecrop

Summer Hyacinth

Sunflower

Sweet Flag

Sweet Sultan

Sweet William

Thrift

Thyme

Turtle Head

Violet

Virginian Cowslip

Wake Robin

Wild Senna

Wild Sweet William

Windflower

Yarrow
BOTANICAL NAME.

Tradescantia

Anthericum liliastrum

Sedum

Galtonia

Helianthus

Acorus

Centaurea macrocephala

Dianthus barbatus

Armeria

Thymus

Chelone

Viola

Mertensia

Trillium

Cassia

Phlox divaricata

Anemone japonica

Achillea
Page

3 I

20

30

$2+$

25

I9

22

23

20

3 I

22

3 I

28

$3 \mathrm{I}$

22

29

I 9

I 9

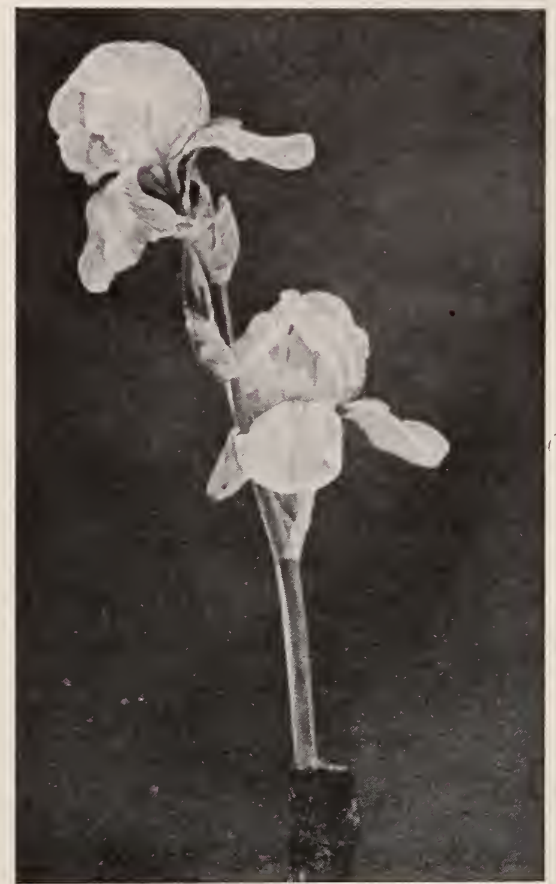

IRIS GERMANICA, HER MAJESTY. SEE PAGE IO. 



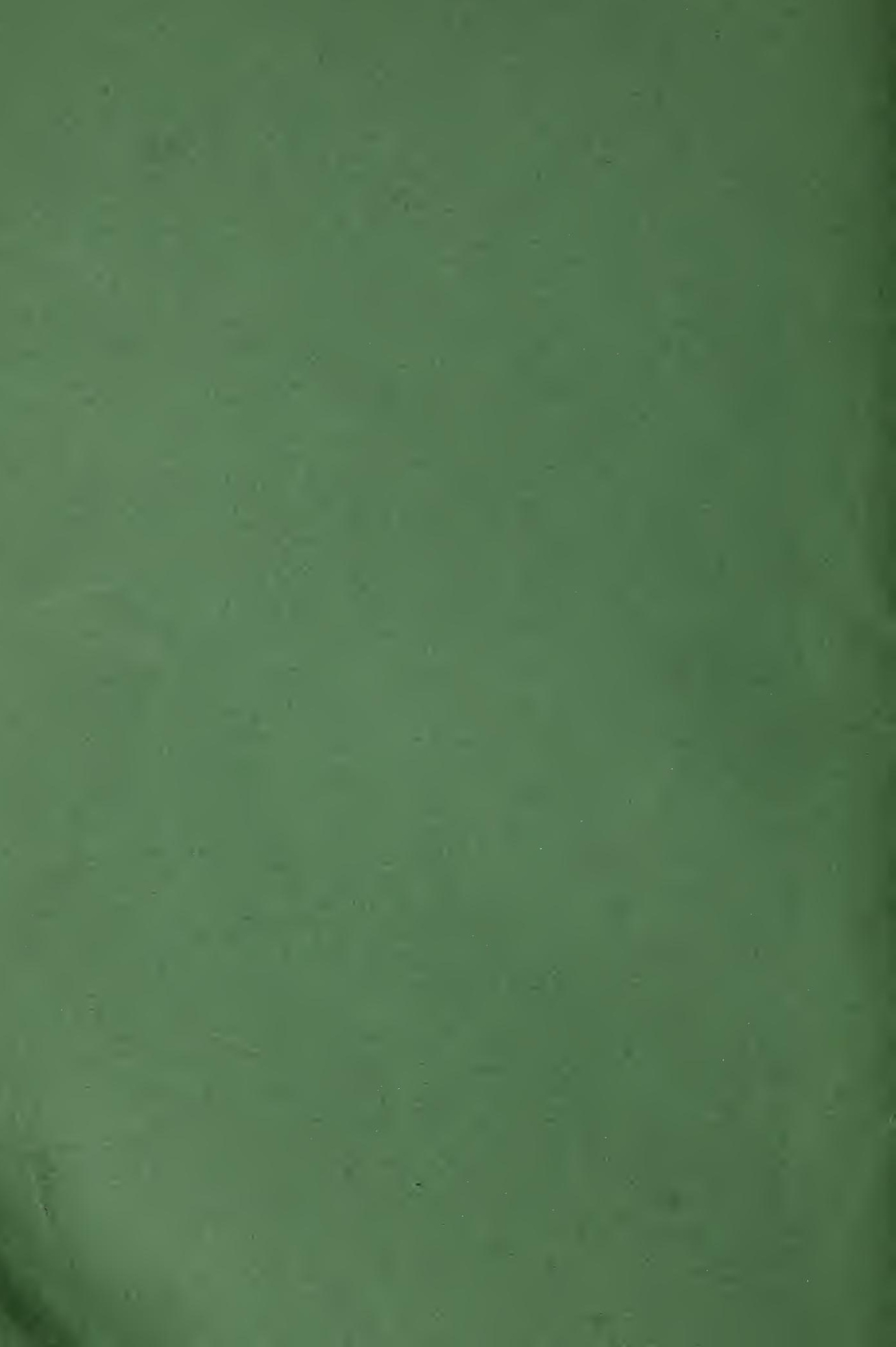

